\title{
Comparing India's Counterinsurgency Approaches in Sri Lanka and Against the Naxalites
}

\author{
A Monograph \\ by \\ MAJ Jason M. Wingeart \\ United States Army

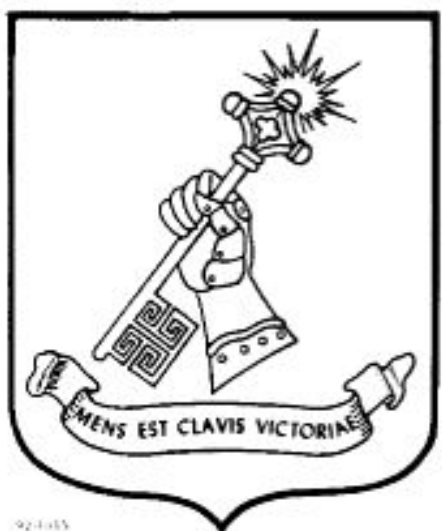 \\ School of Advanced Military Studies \\ United States Army Command and General Staff College \\ Fort Leavenworth, Kansas \\ 2015-01
}




\begin{tabular}{|c|c|c|c|c|}
\hline \multicolumn{4}{|c|}{ REPORT DOCUMENTATION PAGE } & $\begin{array}{l}\text { Form Approved } \\
\text { OMB No. 0704-0188 }\end{array}$ \\
\hline \multicolumn{5}{|c|}{ 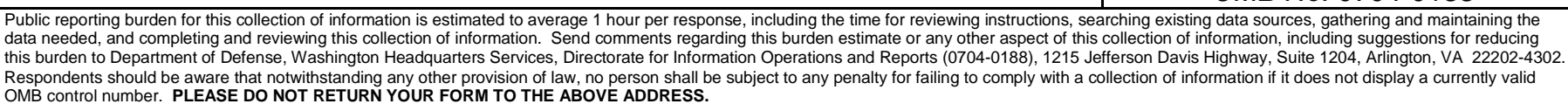 } \\
\hline $\begin{array}{l}\text { 1. REPORT DATE (DD-MM-YYYY) } \\
21-05-2015\end{array}$ & \multicolumn{3}{|c|}{$\begin{array}{l}\text { 2. REPORT TYPE } \\
\text { Master's Thesis }\end{array}$} & $\begin{array}{l}\text { 3. DATES COVERED (From - To) } \\
\text { JUN 2014-MAY } 2015\end{array}$ \\
\hline \multirow{3}{*}{\multicolumn{4}{|c|}{$\begin{array}{l}\text { 4. TITLE AND SUBTITLE } \\
\text { Comparing India's Counterinsurgency Approaches in Sri Lanka and Against the } \\
\text { Naxalites }\end{array}$}} & 5a. CONTRACT NUMBER \\
\hline & & & & 5b. GRANT NUMBER \\
\hline & & & & 5c. PROGRAM ELEMENT NUMBER \\
\hline \multirow{4}{*}{\multicolumn{4}{|c|}{$\begin{array}{l}\text { 6. AUTHOR(S) } \\
\text { Jason M. Wingeart } \\
\text { Major, United States Army }\end{array}$}} & \multirow[t]{2}{*}{ 5d. PROJECT NUMBER } \\
\hline & & & & \\
\hline & & & & 5e. TASK NUMBER \\
\hline & & & & 5f. WORK UNIT NUMBER \\
\hline \multicolumn{4}{|c|}{$\begin{array}{l}\text { U.S. Army Command and General Staff College } \\
\text { ATTN: ATZL-SWD-GD } \\
\text { Fort Leavenworth, KS 66027-2301 }\end{array}$} & $\begin{array}{l}\text { 8. PERFORMING ORGANIZATION } \\
\text { REPORT }\end{array}$ \\
\hline \multirow{2}{*}{\multicolumn{4}{|c|}{$\begin{array}{l}\text { 9. SPONSORING/MONITORING AGENCY NAME(S) AND ADDRESS(ES) } \\
\text { Advanced Military Studies Program }\end{array}$}} & 10. SPONSOR/MONITOR'S ACRONYM(S) \\
\hline & & & & $\begin{array}{l}\text { 11. SPONSOR/MONITOR'S REPORT } \\
\text { NUMBER(S) }\end{array}$ \\
\hline \multicolumn{5}{|c|}{$\begin{array}{l}\text { 12. DISTRIBUTION / AVAILABILITY STATEMENT } \\
\text { Approved for Public Release: Distribution is Unlimited }\end{array}$} \\
\hline \multicolumn{5}{|l|}{ 13. SUPPLEMENTARY NOTES } \\
\hline \multicolumn{5}{|c|}{$\begin{array}{l}\text { 14. ABSTRACT } \\
\text { India possesses a rich history of combating insurgencies throughout its country. The Naxalite movement originated } \\
\text { when India gained its independence and now seventy years later presents the greatest insurgency threat. India also } \\
\text { experienced a pivotal counterinsurgency experience as a third party actor in Sri Lanka. This research study sought to } \\
\text { compare the influence of India's external counterinsurgency approaches in Sri Lanka to their domestic approaches } \\
\text { against the Naxalites. The methodology for this research consists of analyzing each case study for the appearance or } \\
\text { absence of twenty-four counterinsurgency approaches. This research found no evidence of counterinsurgency } \\
\text { operations in Sri Lanka influencing future domestic counterinsurgency operations against the Naxalites. The major } \\
\text { counterinsurgency findings include the necessity to enact political reform; to reduce insurgent support; to recruit, } \\
\text { train, and employ local security forces; to co-opt the population; and to achieve unity of effort. }\end{array}$} \\
\hline \multicolumn{5}{|c|}{$\begin{array}{l}\text { 15. SUBJECT TERMS } \\
\text { India, Counterinsurgency, Naxalites, Sri Lanka }\end{array}$} \\
\hline \multicolumn{2}{|l|}{ 16. SECURITY CLASSIFICATION OF: } & $\begin{array}{l}\text { 17. LIMITATION } \\
\text { OF ABSTRACT }\end{array}$ & \multirow{2}{*}{$\begin{array}{l}\text { 18. NUMBER } \\
\text { OF PAGES } \\
75\end{array}$} & $\begin{array}{l}\text { 19a. NAME OF RESPONSIBLE } \\
\text { PERSON } \\
\text { MAJ Jason Wingeart }\end{array}$ \\
\hline $\begin{array}{l}\text { b. ABSTRACT } \\
(\mathrm{U})\end{array}$ & $\begin{array}{l}\text { c. THIS PAGE } \\
\text { (U) }\end{array}$ & & & $\begin{array}{l}\text { 19b. TELEPHONE NUMBER (include } \\
\text { area code) }\end{array}$ \\
\hline
\end{tabular}




\section{Monograph Approval Page}

Name of Candidate: $\quad$ MAJ Jason M. Wingeart

Monograph Title: Comparing India’s Counterinsurgency Approaches in Sri Lanka and Against the Naxalites

Approved by:

\section{Monograph Director}

Michael D. Mihalka, PhD

, Seminar Leader

James W. MacGregor, COL

, Director, School of Advanced Military Studies

Henry A. Arnold III, COL

Accepted this $21^{\text {st }}$ day of May 2015 by:

, Director, Graduate Degree Programs

Robert F. Baumann, PhD

The opinions and conclusions expressed herein are those of the student author, and do not necessarily represent the views of the U.S. Army Command and General Staff College or any other government agency. (References to this study should include the foregoing statement.) 


\begin{abstract}
Comparing India’s Counterinsurgency Approach in Sri Lanka Against the Naxalites, by MAJ Jason M. Wingeart, 74 pages.

India possesses a rich history of combating insurgencies throughout its country. The Naxalite movement originated when India gained its independence and now seventy years later presents the greatest insurgency threat. India also experienced a pivotal counterinsurgency experience as a third party actor in Sri Lanka. This research study sought to compare the influence of India's external counterinsurgency approaches in Sri Lanka to their domestic approaches against the Naxalites. The methodology for this research consists of analyzing each case study for the appearance or absence of twenty-four counterinsurgency approaches. This research found no evidence of counterinsurgency operations in Sri Lanka influencing future domestic counterinsurgency operations against the Naxalites. The major counterinsurgency findings include the necessity to enact political reform; to reduce insurgent support; to recruit, train, and employ local security forces; to co-opt the population; and to achieve unity of effort.
\end{abstract}




\section{Acknowledgements}

I would like to thank LTC Christopher Coglianese who's time and effort improved the depth of understanding for this research project by providing contact information that led to additional primary sources. 


\section{Table of Contents}

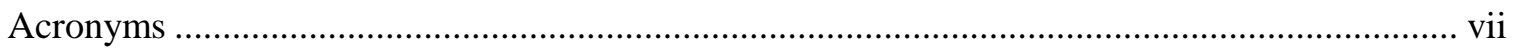

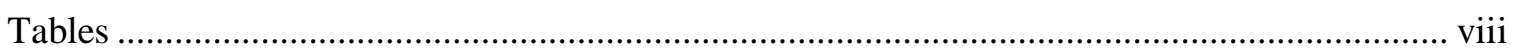

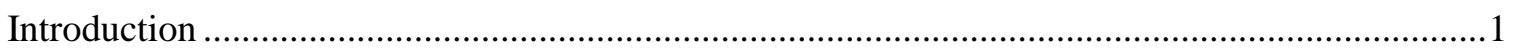

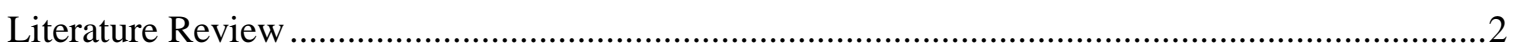

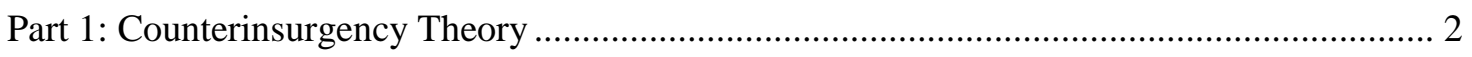

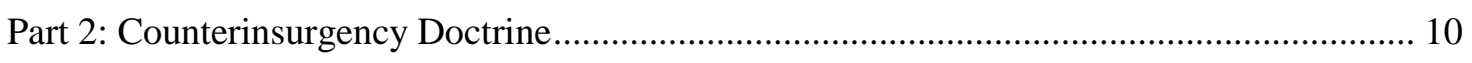

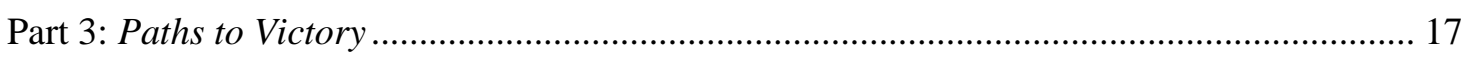

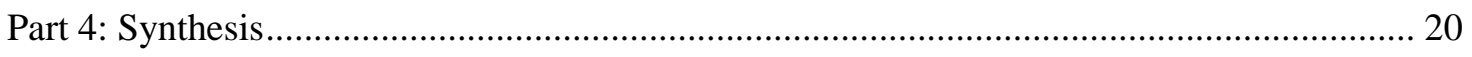

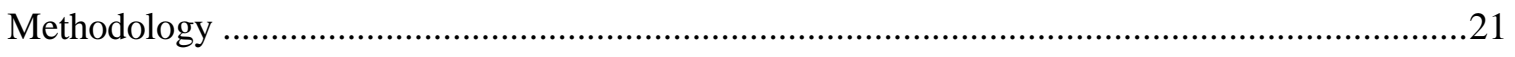

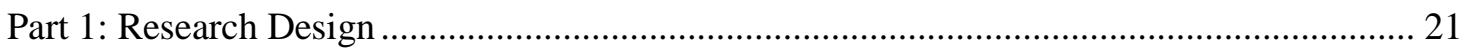

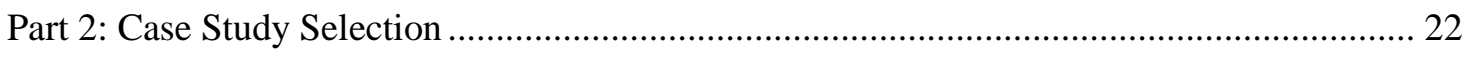

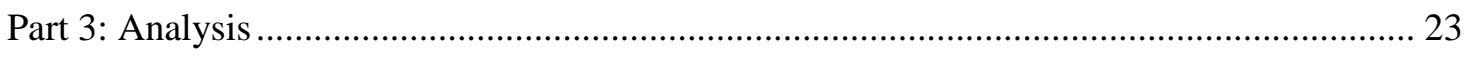

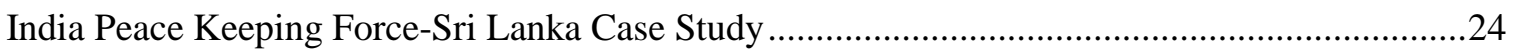

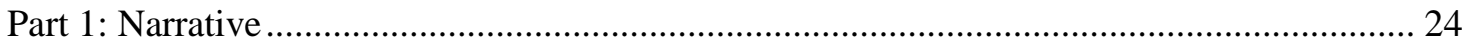

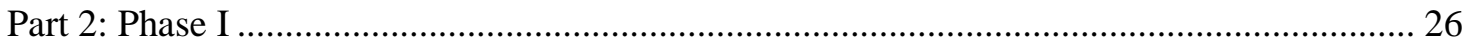

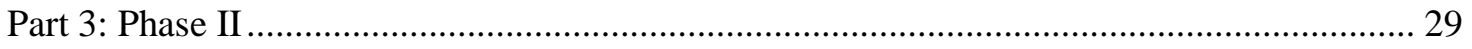

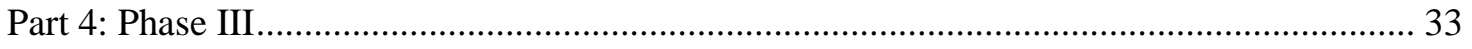

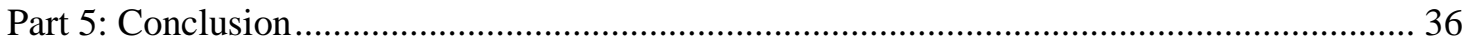

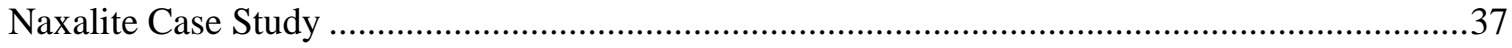

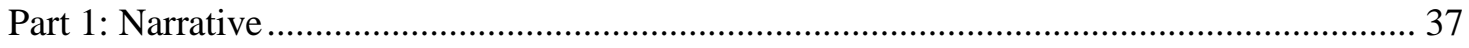

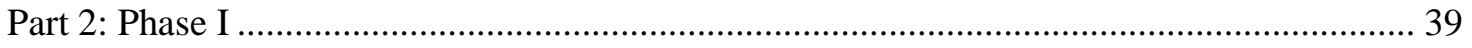

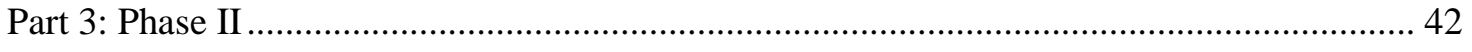

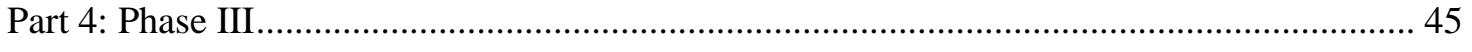

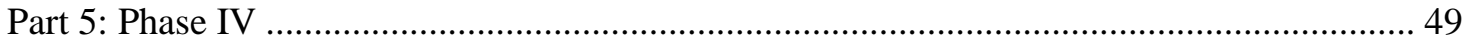

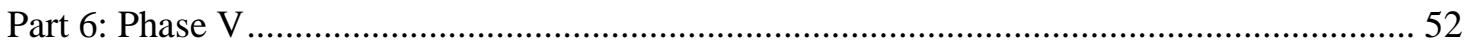

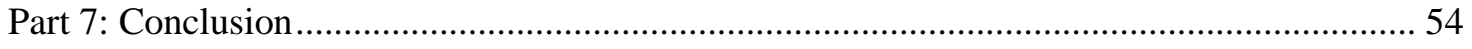




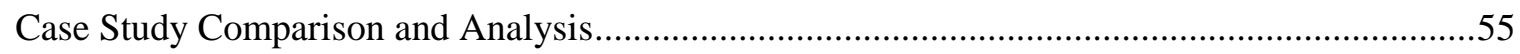

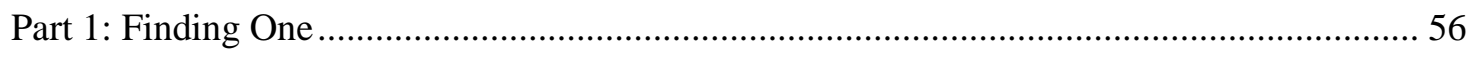

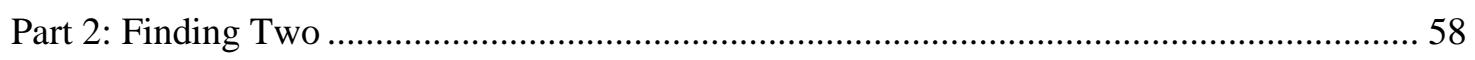

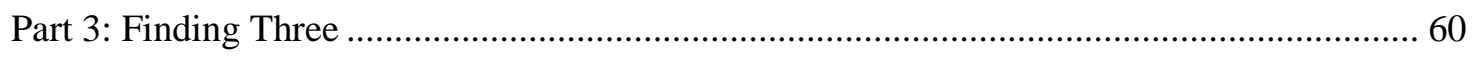

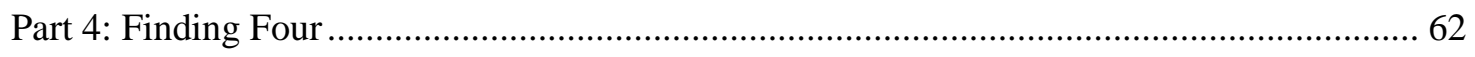

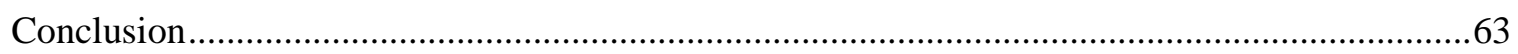

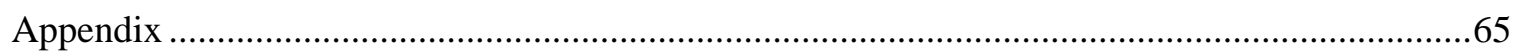

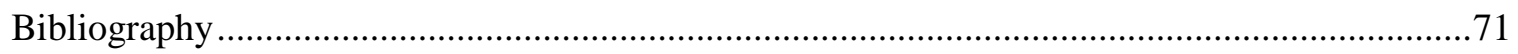




\section{Acronyms}

$\begin{array}{ll}\text { CPI } & \text { Communist Party of India } \\ \text { CPI-LM } & \text { Communist Party of India-Marxist Leninist } \\ \text { CPI-M } & \text { Communist Party of India-Marxist } \\ \text { CPI-Maoist } & \text { Communist Party of India-Maoist } \\ \text { EPRLF } & \text { Ealam People’s Revolutionary Liberation Front } \\ \text { FM } & \text { Field Manual } \\ \text { IPKF } & \text { Indian Peace Keeping Force } \\ \text { JP } & \text { Joint Publication } \\ \text { LTTE } & \text { Liberation Tigers of Tamil Eelam } \\ \text { PWG } & \text { Peoples War Group } \\ \text { RAND } & \text { Research and Development }\end{array}$




\section{Tables}

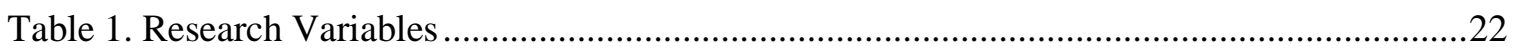

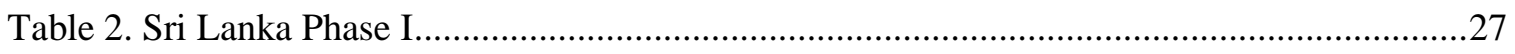

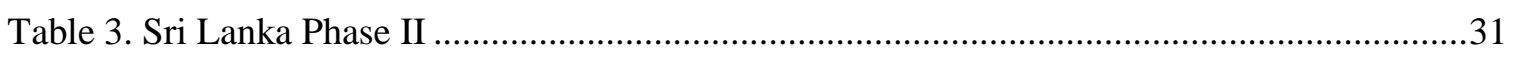

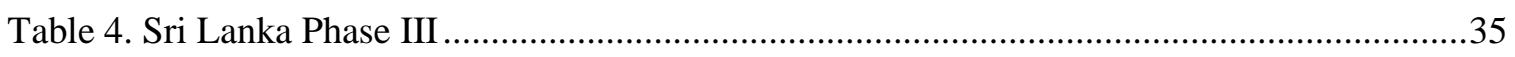

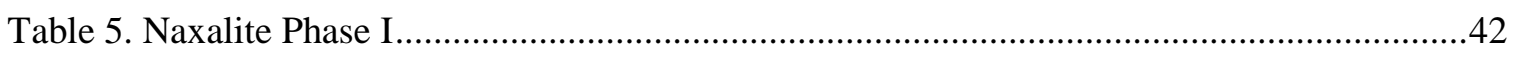

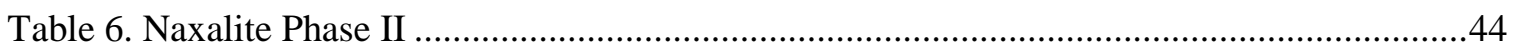

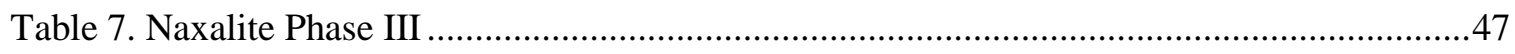

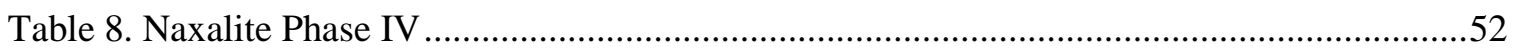

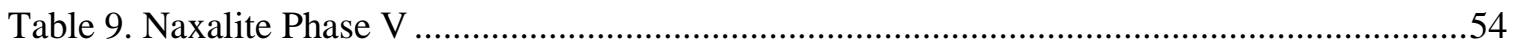

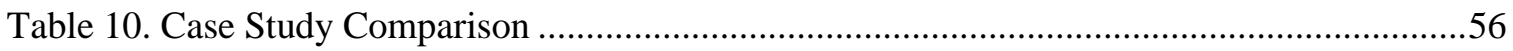


Introduction

We hate COIN, we hate counterinsurgency, and we will never do it again until we do it again.

—Colonel Peter Mansoor (retired), Foreign Policy

Insurgencies have and will continue to threaten governments around the world. How governments and their militaries, conduct counterinsurgency varies from country to country. These variations occur for different reasons and therefore make it difficult to generalize the use of counterinsurgency. This makes research even more important to the understanding and effects of counterinsurgency operations. Additionally, critical to any learning organization is the use of history and previous experiences. Recent United States military experience comes from operations in Iraq and Afghanistan, but other countries have a long and/or recent history of counterinsurgency operations. The United States’ perspective is as a third party entity coming from the outside to assist a host nation with their own insurgency issues. The United States must understand operations from this external actor perspective and must also understand operations from the perspective of the host nation. Finally, it is just as important to understand the similarities and differences between these perspectives. As the United States moves forward with a focus on maintaining the status quo within other countries, it behooves the military to look outside of its own experience to learn from others.

The primary research question of this study is: how does India's counterinsurgency approach against the Naxalites compare to their experience in Sri Lanka? The hypothesis is that India’s Sri Lankan experience influenced their counterinsurgency approach towards future Naxalite operations. The next section of this paper will start with a summary of counterinsurgency literature relevant to this research question. The third section will outline the 
methodology chosen to test the hypothesis and therefore answer the research question. Sections four and five provide the specific case studies researched and analyzed. Section four outlines and analyzes India’s Peace Keeping Force’s (IPKF) operations in Sri Lanka from 1987-1990. Section five outlines and analyzes the Naxalite insurgency. Section six compares and analyzes the data from both case studies. Section seven, the conclusion, will combine each analysis to test the hypothesis and thereby answer the research question. Additionally, the conclusion also includes a recommendation for future research.

\section{Literature Review}

This section provides an overview of the counterinsurgency literature reviewed to undertake the analysis of this research. The purpose of this literature review is to provide a foundational understanding of relevant and influential counterinsurgency theories, practices, and doctrine. It is not all encompassing; instead, it focuses on the most applicable sources in relation to the research question and methodology. This section consists of four parts. The first part looks at overarching counterinsurgency theories. The second part focuses on counterinsurgency doctrine. The third part details the background and results of the study conducted by the Research and Development (RAND) Corporation in Paths to Victory. This work provides the basis for the methodology used to analyze the case studies. The final part provides a synthesis of the counterinsurgency literature and the rationale for the selection of the case studies.

\section{Part 1: Counterinsurgency Theory}

The primary purpose of counterinsurgency focuses on the restoration of governmental legitimacy. ${ }^{1}$ The government gains legitimacy of its population by providing security, peace, and

\footnotetext{
${ }^{1}$ Thomas Marks, "Counterinsurgency and Operational Art," Low Intensity Conflict and
} Law Enforcement, 13, no. 3 (2005): 170, accessed August 5, 2014, http://www.tandfonline.com/doi/pdf/10.1080/09662840600560527. 
prosperity. ${ }^{2}$ This concept places the population as the center of gravity for both the insurgent and the counterinsurgent. ${ }^{3}$ As David Galula explains, "in the final analysis, the exercise of political power depends on the tacit or explicit agreement of the population or, at worst, on its submissiveness." ${ }^{4}$ Insurgency theory discusses three principal views to achieve the support of the population. ${ }^{5}$ An insurgency can win the allegiance of the population, control the population with violence, or use a combination of the two. ${ }^{6}$

The counterinsurgent must understand the insurgent's strategy. Carl von Clausewitz, a theorist of war, posits that "the first, the supreme, the most far-reaching act of judgment that the statesman and commander have to make is to establish by that test the kind of war on which they are embarking; neither mistaking it for, nor trying to turn it into, something that is alien to its nature." 7 The fight for the allegiance of the population requires the counterinsurgent to eliminate the grievance of the insurgency. ${ }^{8}$ In a contest where the enemy uses violence to control the population, the counterinsurgent must adopt a “population and resource control” strategy to protect the people and isolate them from the insurgent. ${ }^{9}$ Finally, a combined strategy by the insurgent requires a similar hybrid method from the counterinsurgent. While these three methods

${ }^{2}$ David Kilcullen, The Accidental Guerrilla: Fighting Small Wars in the Midst of a Big One (New York: Oxford University Press, 2009), 66.

${ }^{3}$ Ibid.

${ }^{4}$ David Galula, Counterinsurgency Warfare: Theory and Practice (St. Petersburg, FL: Hailer, 2005), 8.

${ }^{5}$ Marks, "Counterinsurgency and Operational Art," 168.

${ }^{6}$ Ibid.

${ }^{7}$ Carl von Clausewitz, On War, Indexed Edition, Reprint ed. (Princeton, NJ: Princeton University Press, 1989), 88.

${ }^{8}$ Marks, "Counterinsurgency and Operational Art," 170.

${ }^{9}$ Ibid. 
seem clear and distinct, in actuality the complexity of the situation far exceeds the

aforementioned methods. In the same war, a counterinsurgent may face all three strategies by an insurgent in different areas and/or an environment where the enemy constantly changes the strategy in one area.

The counterinsurgent must understand the insurgent's strategy. Once understood the counterinsurgent can focus on separating, both physically and psychologically, the population from the insurgent. ${ }^{10}$ This allows the counterinsurgent to set the conditions necessary to achieve the political legitimacy desired by the government. The counterinsurgent can achieve that aim using one of three broad strategies. ${ }^{11}$ In a traditional warfare style, an enemy-centric strategy attempts to eliminate the insurgent threat first, setting the conditions for everything else to occur. ${ }^{12}$ A population-centric strategy focuses on establishing control over the population, enabling resolution of the conflict. ${ }^{13}$ While opinions differ, as to which strategy is the most successful, modern counterinsurgency theorists articulate a requirement for both. ${ }^{14}$ Based on the dynamic environment of war, each situation is separate, distinct, and therefore situation dependent. $^{15}$

Clausewitz also recognized that war possesses an enduring quality and warfare consists of an evolving nature. Sir General Frank Kitson, a British counterinsurgency theorist and

${ }^{10}$ Galula, Counterinsurgency Warfare: Theory and Practice, 87-115.

${ }^{11}$ David Kilcullen, “Two Schools of Classical Counterinsurgency,” Small Wars Journal (January 27, 2007): 1, accessed September 30, 2014, http://smallwarsjournal.com/blog/twoschools-of-classical-counterinsurgency.

${ }^{12}$ Ibid.

${ }^{13}$ Ibid.

${ }^{14}$ Ibid.

${ }^{15}$ Emile Simpson, War from the Ground Up: Twenty-First Century Combat as Politics (Crises in World Politics) (New York: Oxford University Press, 2012), 149. 
practitioner, recognizes the same aspects within counterinsurgency. ${ }^{16}$ Kitson suggests counterinsurgents must establish the proper framework in an effort to conduct a successful campaign against an insurgency. ${ }^{17}$ The counterinsurgent must establish an effective and efficient command structure to achieve unity of effort at all levels. ${ }^{18}$ For example, the organizational structure of the intelligence community must fit the circumstances faced by the counterinsurgent. ${ }^{19}$ Intelligence requirements differ at each level of command and therefore require a tailored intelligence structure that supports each level of authority. ${ }^{20}$ Additionally, Kitson mandates that the counterinsurgent must "win the war for the minds of the people.”21 Moreover, all actions executed by the government must be legal, for it is this same authority by which the government expects its citizens to adhere to both during the conflict and afterwards. ${ }^{22}$ While each aspect possesses an enduring quality that successful counterinsurgents need to establish, they are not static, but instead each one must also adapt as circumstances change.

Echoing some of the same themes proposed by Kitson, Sir Robert Thompson, a British Administrator during the Malaya Emergency and advisor to the US military during the Vietnam War, focuses his counterinsurgency theories at the governmental level. Thompson discusses the

16 "Nature and Character of War and Warfare," Maneuver Self-Study Program, April 25, 2014, accessed August 10, 2014, http://www.benning.army.mil/mssp/Nature\%20and\%20Character/. Sir Frank Kitson served as a midgrade officer during the Malaysian Emergency, a senior officer in Ireland, and eventually become the Commander-in-Chief of all United Kingdom Land Forces.

${ }^{17}$ Frank Kitson, Bunch of Five (London: Faber and Faber, 2011), 290.

${ }^{18}$ Ibid., 284.

${ }^{19}$ Ibid., 287.

${ }^{20}$ Ibid.

${ }^{21}$ Ibid., 291.

22 Ibid., 289. 
requirement for governments to establish a clear political aim. ${ }^{23}$ Reiterating Kitson’s idea, Thompson also stresses the need for the government to operate within the law. ${ }^{24}$ Additionally, the government should develop and implement a comprehensive plan with a specific emphasis on defeating political subversion. ${ }^{25}$ Finally, Thompson articulates the need for the government to secure its base of support, which allows for future expansion into contested areas. ${ }^{26}$

Joseph Gallieni, a French military officer during the turn of the $20^{\text {th }}$ Century, fathered the "oil stain” metaphor for counterinsurgency theory. ${ }^{27}$ When oil leaks onto the ground, the heaviest concentration starts and remains at the initial location, but over time, the oil will spread out from the center into the surrounding areas. ${ }^{28}$ Essentially, Gallieni’s “oil stain theory” describes the process of having the counterinsurgent start from a position of advantage by establishing security and methodically extending that control into contested zones and insurgent controlled zones. ${ }^{29}$ This methodical expansion generally requires more time to execute than its inverse strategy. ${ }^{30}$

As David Galula explains, the opposite strategy, if it works, resolves the situation faster. ${ }^{31}$ This concept starts not from a position of advantage, but at the heart of insurgent held and influenced territory to remove their base of support to expose and subsequently defeat the

23 Thomas Mockaitis, "The British Experience in Counterinsurgency 1919-1960" (PhD diss., University of Wisconsin-Madison, 1988), 397.

${ }^{24}$ Ibid.

${ }^{25}$ Ibid., 398.

${ }^{26}$ Ibid.

${ }^{27}$ Anthony J. Joes, Resisting Rebellion: The History and Politics of Counterinsurgency (Lexington, KY: University Press of Kentucky, 2004), 219.

${ }^{28}$ Thomas Rid and Thomas Keaney, eds., Understanding Counterinsurgency: Doctrine, Operations, and Challenges (New York: Routledge, 2010), 13.

${ }^{29}$ Joes, Resisting Rebellion: The History and Politics of Counterinsurgency, 219.

${ }^{30}$ Galula, Counterinsurgency Warfare: Theory and Practice, 97.

${ }^{31}$ Ibid. 
enemy. ${ }^{32}$ While this strategy offers the possibility of resolving the situation faster, an unsuccessful start could likewise spell disaster just as quickly.

Roger Trinquier, a French military officer who served in both Vietnam and Algeria, is both a theorist and practitioner and argues that the counterinsurgent should focus on the most dense population centers. ${ }^{33}$ He supports his argument through the assertion that, "it is accepted that the final stake of modern warfare is the control of the population.”34 Therefore, crucial to the success of a counterinsurgency campaign includes concentrating on the areas with the largest populations. ${ }^{35}$ He also recognizes that military operations alone are not sufficient, but instead they are a component of a larger strategy. ${ }^{36}$ He argues for a whole of government approach that consists of political, economic, military, and psychological operations against the insurgent. ${ }^{37}$ Trinquier's vision for victory occurs by defeating the enemy's political organization. ${ }^{38}$ This vision combines both concepts of population control and enemy focused operations to achieve a cumulative effect against the opposition.

A RAND project written by Austin Long provides two contradictory theories. The "hearts and mind" theory posits that the government must convince the population that they can

${ }^{32}$ Galula, Counterinsurgency Warfare: Theory and Practice, 97.

${ }^{33}$ Roger Trinquier, A French View of Counterinsurgency (Fort Leavenworth, KS: Combat Studies Institute Press, U.S Army Command and General Staff College, 1985), vii-104.

${ }^{34}$ Ibid., 104.

${ }^{35}$ Ibid. The Russians express a slight variation of Trinquier's method and combine it with that of Gallieni. One of their five principles developed during the nineteenth century to deal with insurgency focuses on controlling the central cities and expanding their influence outward to the surrounding areas. Joes, Resisting Rebellion: the History and Politics of Counterinsurgency, 225.

36 Trinquier, A French View of Counterinsurgency, 65.

${ }^{37}$ Ibid., 5.

${ }^{38}$ Ibid., 9. 
provide security and meet both their short and long-term interests. ${ }^{39}$ This theory rests upon the assumption that the government at one point provided security and acted for the benefit of the people. ${ }^{40}$ As a result, the government simply needs to reassert itself to restore the hope and balance that previously existed. ${ }^{41}$ On the opposite end of the spectrum rests the cost/benefit theory. The cost/benefit theory essentially refers to Charles Tilly, a European history expert and a political theorist, who wrote a theory of how states use capital and coercion to control the population. ${ }^{42}$ Tilly writes that states who are able to balance the use of incentives offered to the population while applying the right amount of disincentives to join the insurgency gains the support of the people and therefore wins. ${ }^{43}$ This theory assumes the population acts rationally, meaning they respond in predictable ways to either the carrot or the stick approach. ${ }^{44}$

An irregular warfare theorist, Stathis Kalyvas proposes a theory of irregular war, which describes that the most critical goal for the counterinsurgent must be to gain the collaboration of the population. ${ }^{45}$ Kalyvas expects collaboration to occur through a series of control mechanisms. ${ }^{46}$ Two mechanisms include the use of resettlement and violence. A counterinsurgent

${ }^{39}$ Austin Long, On "Other War" Lessons from Five Decades of RAND Counterinsurgency Research (Santa Monica: RAND Corporation, 2006), x.

${ }^{40}$ Ibid., 23.

${ }^{41}$ Ibid.

${ }^{42}$ Charles Tilly, Coercion, Capital, and European States, AD 990-1992, rev. ed. (Cambridge, MA: Wiley-Blackwell, 1992), 16.

${ }^{43}$ Long, On "Other War" Lessons from Five Decades of RAND Counterinsurgency Research, 25.

${ }^{44}$ Ibid.

${ }^{45}$ Stathis N. Kalyvas, The Logic of Violence in Civil War (New York: Cambridge University Press, 2006), 111.

${ }^{46}$ Ibid., 118. 
undertakes a population resettlement program to separate the population from the insurgent. ${ }^{47}$ Once separated, the counterinsurgent must control the population and provide them security from insurgent attacks as pre-cursors to gain additional collaboration. ${ }^{48}$

The second mechanism Kalyvas describes actually equates to its own theory, the theory of violence. Building on the idea that collaboration is of the utmost importance, Kalyvas discusses the use of violence to control the population. For violence to be effective, the purpose behind its use must be understood by the population and therefore, selective in nature. ${ }^{49}$ Kalyvas posits that if the population understands why a certain individual was targeted it should reduce the likelihood of other individuals from committing the same unwanted behaviors. ${ }^{50}$ Indiscriminate violence, on the other hand, cannot have a positive influence on future actions because of its random nature. ${ }^{51}$

Mikhail Tukhachevsky, a Russian military practitioner and theorist, proposes one of the best incentives to use during a counterinsurgency campaign is to offer timely amnesty. ${ }^{52}$ At the time of his writing, the idea of amnesty was not a new concept. ${ }^{53}$ However, the contribution Tukhachevsky makes narrows in on when to offer amnesty. When done correctly, amnesty efforts should coincide with other methods used to force the insurgent into looking for a way out. ${ }^{54}$ The

${ }^{47}$ Kalyvas, The Logic of Violence in Civil War, 122.

${ }^{48}$ Ibid.

${ }^{49}$ Ibid., 180.

${ }^{50}$ Ibid., 122.

${ }^{51}$ Ibid., 143.

52 Joes, Resisting Rebellion: The History and Politics of Counterinsurgency, 226.

${ }^{53}$ Ibid., 223. The Chinese used amnesty as one of their preferred methods of conflict resolution.

${ }^{54}$ Ibid., 226. 
preferred method for Tukhachevsky is to recruit an insurgent to assist with the fight against their former comrades. ${ }^{55}$ These individuals provide valuable intelligence to the counterinsurgent about the insurgency, which facilitates understanding and effective operations. Furthermore, he cautions against offering an insurgent amnesty when the conditions or initiative favors the enemy because it shows a sign of weakness that can actually boost support for the insurgent's cause. ${ }^{56}$

\section{Part 2: Counterinsurgency Doctrine}

According to US joint military doctrine Joint Publication 3-24, a comprehensive approach to counterinsurgency includes the right combination of information, economic, and security components applied through an overarching political strategy in an effort to achieve control of the population and thereby gain legitimacy for the host nation government. ${ }^{57}$ The tenets outlined at the joint level include: understand the operational environment, develop the counterinsurgency narrative, recognize the primacy of politics, secure the population, synchronize and integrate lines of effort, as well as to achieve unity of command and unity of effort. ${ }^{58}$ At the joint level, the US military identifies five distinct operational approaches to counterinsurgency. The first approach is to conduct counterinsurgency operations with or in place of host nation forces; the United States calls this foreign internal defense. ${ }^{59}$ The second approach focuses on isolating the insurgents both physically and psychologically. ${ }^{60}$ The third approach uses

55 Joes, Resisting Rebellion: The History and Politics of Counterinsurgency, 226.

${ }^{56}$ Ibid.

57 Joint Publication (JP) 3-24, Counterinsurgency (Washington, DC: Government Printing Office, 2013), III-5.

${ }^{58}$ Ibid., III-7-15.

${ }^{59}$ Ibid., III-23.

${ }^{60}$ Ibid. 
disaggregation to divide and conquer smaller factions of the insurgency. ${ }^{61}$ The fourth approach addresses the root cause of the problem through diplomacy in an effort to end the insurgency. ${ }^{62}$ The fifth approach attempts to defeat an insurgency by neutralizing them in detail over time by deciding where and when to concentrate efforts and to accept risk. ${ }^{63}$ This doctrine serves as the foundation from which the joint force develops and implements counterinsurgency operations and tactics.

US Army Field Manual 3-24: Insurgencies and Countering Insurgencies starts with setting the strategic context within which the army operates. At the strategic level, the US government, in conjunction with the military, determines the right application of ends, ways, and means while balancing the risk. ${ }^{64}$ Gaining legitimacy for the host nation government through the exercise of control over their population should guide decision makers during the conduct of counterinsurgency operations. ${ }^{65}$ To support that aim, the Army starts by understanding the operational environment within which it will operate. ${ }^{66}$

Part of understanding the operational environment is understanding the enemy. Insurgents generally employ one or a combination of four different approaches. ${ }^{67}$ The first is the urban approach, wherein the insurgents attack the government to force an overly aggressive

${ }^{61}$ JP 3-24, Counterinsurgency, III-24.

62 Ibid., III-25.

${ }^{63}$ Ibid.

${ }^{64}$ Field Manual (FM) 3-24, Insurgencies and Countering Insurgencies (Washington, DC: Government Printing Office, 2014), 1-5.

65 Ibid., 1-8.

${ }^{66}$ Ibid., 2-1.

${ }^{67}$ Ibid., 4-7. 
retaliation by the government on the population at large. ${ }^{68}$ The second is the military-focused approach, where the insurgents attack the military to delegitimize the government and gain popular support through tactical victories. ${ }^{69}$ The third is the protracted approach, based on Mao Tse-Tung's theory of popular war. ${ }^{70}$ The protracted approach requires both a military and political wing and possesses "three distinct phases: latent and incipient, guerrilla warfare, and war of movement."71 The fourth is the subversive approach, where the insurgents "attempt to subvert the government from within by using its political arm to become a legitimate political party and enter the government. ${ }^{72}$

Once the counterinsurgent understands the operational environment and the enemy, it can then apply one or a combination of approaches. One uses the shape-clear-hold-build-transition as a framework. ${ }^{73}$ This framework attempts to "destroy insurgents capacity and empower hostnation capacity."74 The concept is fluid in order to allow adjustments based on the evolving conditions, but generally represents the overall progression. ${ }^{75}$ Providing assistance and

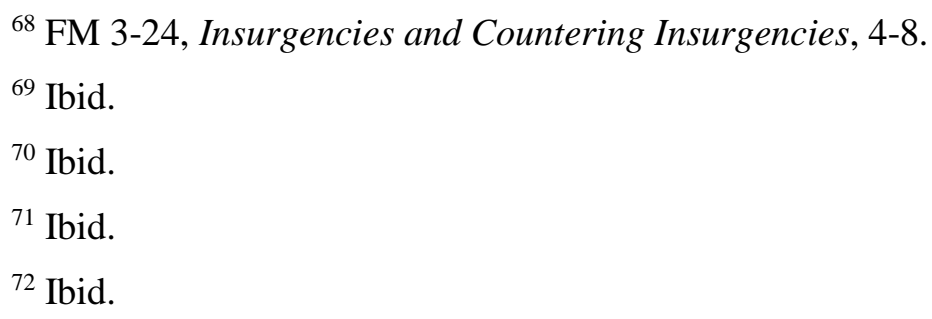
operations or other methods, that create the conditions for success of the other phases ... The clear phase is an effort to remove the open insurgent presence in an area. The hold phase is defined by providing security for the population in an area so an open insurgent presence cannot return. The build phase entails efforts to increase security and governmental capacity so that government and local forces can control the area and prevent the return of insurgents. The transition phase is the transition of security to local and government forces.” Ibid., 9-1.

$$
\begin{aligned}
& { }^{74} \text { Ibid., 9-3. } \\
& { }^{75} \text { Ibid. }
\end{aligned}
$$


cooperation to both the government and military forces is another approach. ${ }^{76}$ The counterinsurgent can also use "negotiation and diplomacy," and/or co-option of the population. ${ }^{77}$

India looks at counterinsurgency doctrine through a slightly different lens. India’s history is an important factor to understand when studying its counterinsurgency doctrine. Initially, upon gaining independence from Britain in the late 1940s, India lacked formal military counterinsurgency doctrine. ${ }^{78}$ However, what it lacked in written history, India made up with experience working alongside and against the British for over 150 years. ${ }^{79}$ While Indian military experts disagree to the extent of British influence on counterinsurgency operations, there are a few noticeable similarities. Britain espoused the importance of respecting the local culture and using the smallest force possible.$^{80}$ The British also utilized mass village-wide punishments to coerce the population. ${ }^{81}$ Outside of the British influence, the most influential individual for India's counterinsurgency approach was Prime Minister Nehru, who advocated for the resolution of insurgencies using the democratic process. ${ }^{82}$ As a result, it subordinated military action to the

${ }^{76}$ FM 3-24, Insurgencies and Countering Insurgencies, 10-1.

${ }^{77}$ Ibid., 10-6. The FM actually describes two population centric approaches. The first is general engagement that is meant to occur in combination with other approaches and represents the acknowledgement that the population must always be part of the planning factor. The second is more specific as the counterinsurgent attempts to identify, separate, isolate, influence, and reintegrate portions of the population and/or insurgents.

${ }^{78}$ Dipankar Banerjee, "The Indian Army's Counterinsurgency Doctrine," in India and Counterinsurgency: Lessons Learned, ed. Sumit Ganguly and David Fidler (New York: Routledge, 2009), 192.
${ }^{79}$ Ibid.
${ }^{80}$ Ibid.
${ }^{81}$ Ibid.
${ }^{82}$ Ibid., 193. 
political process and restricted the use of the military to a role of "managing the level of violence." 83

Over the next twenty years, India learned from both internal counterinsurgencies and from other countries. Internally, India dealt with the Naga insurgency and it is here that Nehru influenced the conduct of counterinsurgency operations. ${ }^{84}$ Nehru mandated the military employ restraint at all times when applying force to a domestic problem. ${ }^{85}$ Additionally, Nehru pushed for a hearts and minds as well as resettlement approaches, which he saw the British use in Malaysia. ${ }^{86}$ Another influence during this timeframe came from the Chinese as India studied Mao. The major element learned and incorporated by India was the necessity to isolate the guerrilla from the population while maintaining direct influence over the population. ${ }^{87}$ Nehru envisioned the combination of a hearts and minds, a resettlement, and an insurgent separation approach as complementary. Lastly, the Indian military pictured a large concentration of forces in

${ }^{83}$ Banerjee, "The Indian Army's Counterinsurgency Doctrine," 193.

${ }^{84}$ Dinesh Kotwali, "The Naga Insurgency: The Past and the Future," Strategic Analysis Vol XXIV, no. 4 (July 2000): 751-72, accessed February 3, 2015, http://www.idsa-india.org/anjul-700.html. The Naga insurgency started in the Northeast corner of India. Geography isolated the Naga population for most of the British colonial period. After decolonization, the government of India and Naga leaders agreed to terms that pushed off the decision of whether the Naga territory would join India or claim independence. Within months the strategic situation changed, the two sides revisited the question of unity or independence. The actual accounts of these discussions are under debate, but the result was the leaders of Naga declared independence. The Indian government then sought to bring the Naga people under control of the central authority by force while the Naga population established both a military and political wing to run an effective insurgency campaign that continues into the present day.

${ }^{85}$ Rajesh Rajagopalan, Fighting Like a Guerrilla: The Indian Army and Counterinsurgency (New Delhi: Routledge India, 2008), 145.

${ }^{86}$ Banerjee, "The Indian Army's Counterinsurgency Doctrine," 194.

${ }^{87}$ Rajagopalan, Fighting Like a Guerrilla: The Indian Army and Counterinsurgency, 145. 
order to dominate the area and achieve their aims, which was at odds with the light footprint envisioned by Prime Minister Nehru. ${ }^{88}$

In the 1980s, there was one major change in Indian counterinsurgency thought. Prior to this point, while the India government professed the belief that the solution to an insurgency was political; the military remained divided on the subject. ${ }^{89}$ Some believed the military alone could resolve an insurgency. ${ }^{90}$ Regardless of their beliefs, the military dutifully followed orders rather than openly challenge the idea. In the mid-1980s, a shift occurred and the military openly acknowledged and supported this concept as evident from professional writing forums, such as journals and essays. ${ }^{91}$ Now, for the first time, the military advocated for the same overarching approach to counterinsurgency operations. This occurred for two reasons. Up until that point, the Indian Army had not ended any of the five on-going insurgencies. ${ }^{92}$ Second, "preserving the conventional war orientation was more important for the army than maintaining its conviction in a military solution to insurgencies”93

${ }^{88}$ Rajagopalan, Fighting Like a Guerrilla: The Indian Army and Counterinsurgency, 156.

${ }^{89}$ Ibid., 164.

${ }^{90}$ Ibid.

${ }^{91}$ Ibid., 165.

${ }^{92}$ Ibid., 166; Anit Mukherjee, "India's Experiences with Insurgency and Counterinsurgency,” in The Routledge Handbook of Asian Security Studies, ed. Sumit Ganguly, Joseph Liow, and Andrew Scobell (London: Routledge, 2010), 141. The five on-going insurgencies in the mid-1980s included: Naga, Manipur, Mizo, Tripura, and ULFA.

${ }^{93}$ Rajagopalan, Fighting Like a Guerrilla: The Indian Army and Counterinsurgency, 168. 
Current Indian counterinsurgency doctrine professes an "Iron Fist in a Velvet Glove” approach. ${ }^{94}$ This phrase epitomizes the tradition within the military to "fight a guerrilla like a guerilla." ${ }^{95}$ Specifically, the military’s primary role "is to re-establish control so that the civil administration can exercise its proper function.”96 The military envisions a two-step method to achieve its goals. The first step in achieving that goal is to dominate the security arena. ${ }^{97}$ The second step focuses on changing the attitudes of the population to buy into the government's ideology. ${ }^{98}$ The military could employ a number of approaches to assist in either step. One includes the isolation of the conflict area to prevent external support from reaching the opposition. ${ }^{99}$ Another stresses precision strike operations guided by accurate and timely intelligence. ${ }^{100}$ Still others emphasize employing the minimum amount of force necessary. ${ }^{101}$ One more focuses on avoiding large-scale operations in order to minimize collateral damage. ${ }^{102}$

The last approach worth mentioning, while not specifically doctrinal, does articulate how India in the past and currently organizes themselves to combat insurgencies. India has a history of creating paramilitary forces to conduct operations against domestic threats. Over the years, India

${ }^{94}$ Behram A. Sahukar, “The Indian Approach to Counterinsurgency Operations,” Insurgency Research Group, March 6, 2008, accessed November 20, 2014, http://insurgencyresearchgroup.wordpress.com/2008/03/06/the-indian-approach-to-coin/theindian-approach-to-counterinsurgency-operations/.

${ }^{95}$ David P. Fidler, “The Indian Doctrine for Sub-Conventional Operations: Reflections from a U.S. Counterinsurgency Perspective,” in Ganguly and Fidler, 228.

${ }^{96}$ LT COL KMS Rana, “An Analysis of the Indian Army's Coin Experience” (master's thesis, United States Army Command and General Staff College, 2012), 11.

${ }^{97}$ Sahukar, “The Indian Approach to Counterinsurgency Operations.”

${ }^{98}$ Ibid.

${ }^{99}$ Ibid.

${ }^{100}$ Rana, “An Analysis of the Indian Army's Coin Experience,” 11.

${ }^{101}$ Sahukar, "The Indian Approach to Counterinsurgency Operations.”

102 Rana, “An Analysis of the Indian Army's Coin Experience,” 11. 
created three such organizations. The first paramilitary force created, the Assam Rifles, originated in 1835 and exists to this day to combat insurgencies in the northeast. ${ }^{103}$ In 1989, India created the Rashtriya Rifles with the intent of creating a paramilitary counterinsurgency force in the northwest. ${ }^{104}$ However, the Rashtriya Rifles evolved into a unit manned and controlled by the Indian military based on the urgency for forces at the time of creation. ${ }^{105}$ This force remains controversial for elements within portions of the government and military because of their organizational structure. ${ }^{106}$ In 2001, India formed the Central Reserve Police Force to serve as the counterinsurgency force in the central region of the country. ${ }^{107}$ The creation of each force demonstrates India's desire to separate the Indian military from conducting domestic counterinsurgency operations.

\section{Part 3: Paths to Victory}

The existing counterinsurgency literature demonstrates that no common thread exists to provide the counterinsurgent with a recipe for success. Each theory and practice at one point in time produced successful results, but none of them act as the silver bullet solution to every problem. In Victory has a Thousand Fathers: Sources of Success in Counterinsurgency, RAND analyzes thirty historical counterinsurgencies. This research attempts to identify the approaches

103 Banerjee, "The Indian Army's Counterinsurgency Doctrine," 195.

${ }^{104}$ Rajesh Rajagopalan, "Innovations in Counterinsurgency: The Indian Army's Rashtriya Rifles,” Contemporary South Asia 13, no. 1 (March 2004): 29.

105 Ibid.

106 Ibid.

${ }^{107}$ Banerjee, "The Indian Army's Counterinsurgency Doctrine," 195. In addition to the three national level paramilitary forces, some local governments within India have created their own paramilitary forces. 
that influence the outcomes of counterinsurgency campaigns. ${ }^{108}$ Paths to Victory: Lessons from Modern Insurgencies, RAND builds upon the previous study by expanding the number of cases from thirty to seventy-one and increases the depth of analysis. ${ }^{109}$

Paths to Victory chose case studies that begin and end between World War II and 2010 and span the entire globe. ${ }^{110}$ Next, RAND extrapolates twenty-four counterinsurgency concepts from existing literature to test. ${ }^{111}$ The comparative use or absence of these concepts in each case study forms the basis of the research analysis. To assist with analysis, each case study is broken down into phases based on a significant shift in approach made by the counterinsurgent or insurgent. ${ }^{112}$ RAND assigns the outcome of each case in terms of a counterinsurgent win, loss, or mixed results. ${ }^{113}$ Then, using the data compiled for each case study in the final phase, RAND was able to identify fifteen good and eleven bad counterinsurgent practices. ${ }^{114}$ Subtracting the number of bad practices from the good, produces a numerical number that matches the outcome of each

${ }^{108}$ Christopher Paul, Colin P. Clarke, and Beth Grill, Victory Has a Thousand Fathers: Sources of Success in Counterinsurgency (Santa Monica, CA: RAND Corporation, 2010), iii.

${ }^{109}$ Christopher Paul et al., Paths to Victory: Lessons from Modern Insurgencies (Santa Monica, CA: RAND Corporation, 2013), xviii.

${ }^{110}$ Ibid., xviii.

${ }^{111}$ Ibid., 8.

112 Ibid., 16.

${ }^{113}$ Ibid., 201-3. Case outcomes were determined by the following logic. Once the insurgency ended, if the counterinsurgent no longer maintained control and governance over the conflict area either the insurgent won or the result was mixed. If the counterinsurgent maintained control and governance over the conflict area and made no major power sharing deals with the insurgent, the counterinsurgent won. If the government maintained control and governance, but made major concessions with the insurgent to do so, the results were mixed.

114 Ibid., Xxv. 
case. ${ }^{115}$ If the number is positive, the counterinsurgent won, if negative, the counterinsurgent lost. This finding represents one of the key findings by the study.

Six other key findings come from the RAND research study. "Quality is more important than quantity, especially where paramilitaries and irregular forces are concerned.” ${ }^{116}$ Two, "governments supported by external actors win the same way others do.” ${ }^{117}$ The introduction of an external actor is not by itself a bad practice. ${ }^{118}$ Instead, it is more dependent on the relationship between the two governments and militaries as well as the approaches the two actors employ that determine whether they will succeed or not. ${ }^{119}$ Third, successful counterinsurgents always employ numerous effective counterinsurgency practices rather than just a few." ${ }^{120}$ Fourth, "seventeen of the twenty-five concepts received strong support, while only one 'Crush Them' received strong evidence against." ${ }^{121}$ Fifth, "effective counterinsurgency practices run in packs . . . meaning that counterinsurgency forces that defeat insurgencies implement numerous effective practices rather than just a few.” ${ }^{122}$ Finally, three approaches are always present when the counterinsurgent won: tangible support reductions; commitment and motivation; and flexibility and adaptability.

\footnotetext{
${ }^{115}$ Paul et al., Paths to Victory: Lessons from Modern Insurgencies, xxv.

${ }^{116}$ Ibid., Xxviii.

117 Ibid.

118 Ibid., xxix.

119 Ibid.

${ }^{120}$ Ibid., xxiii.

${ }^{121}$ Ibid., xxi. The seventeen concepts that received strong support include: hearts and minds, pacification, legitimacy (government), legitimacy (use of force), reform, unity of effort, cost-benefit, border control, initiative, strategic communication, FM 3-24, clear-hold-build, "beat cop”, "boots on the ground”, commitment and motivation, tangible support reduction, intelligence, and flexibility. Paths to Victory claimed to test only twenty-four concepts. However, RAND divided legitimacy into two sub-components and tested them separately. Therefore, this study views the RAND study as having twenty-five concepts.

122 Ibid., xxiii.
} 
Seventh, primarily focusing on the elimination of the insurgent threat is typically less

successful. ${ }^{123}$

\section{$\underline{\text { Part 4: Synthesis }}$}

There is a variety of ways to achieve success against an insurgency. The literature review highlights a number of concepts developed under case specific conditions, which led to successful or unsuccessful results. The overarching theme in the literature focuses on two concepts: control and co-option. Identified in the literature review are strategies that can generally fall under one of the two concepts or incorporate both simultaneously. Control and co-option apply to both the population and the insurgents.

Depending on the situation, the counterinsurgent may want to apply a number of control mechanisms over the population to gain an acceptable level of security, from which they can apply co-option. Similarly, the counterinsurgent may focus on controlling insurgent actions and options, first before implementing co-option methods. While both examples appear linear in nature, that is control occurs before co-option, neither concept is mutually exclusive. The announcement of a co-option plan prior to the initiation of control measures may plant the seeds of eventual defection. The challenge for the operational planner is to determine what methods to apply, where and when, to achieve the desired effect. Then, once operationalized, the counterinsurgent must continually assess the situation and determine when, if necessary to make a change. With a shared understanding of the prevalent counterinsurgency literature, the next section will discuss the system used to investigate the research question.

${ }^{123}$ Paul et al., Paths to Victory: Lessons from Modern Insurgencies, xxix. 


\section{Methodology}

This section will describe the process undertaken to research India’s counterinsurgency approach. There are three parts to the methodology section. The first part outlines the research design for this study. The second part discusses the selection of the two case studies. The third part describes the conduct of analysis and the limitations affecting this research.

\section{Part 1: Research Design}

This research uses a longitudinal mixed method approach to guide the data collection and analysis. Using a longitudinal study allows this study to assess change within each case study. To do so, this research followed the model in Paths to Victory to divide cases into phases. A phase represents the recognition of a significant shift in the counterinsurgency approaches employed. ${ }^{124}$ The longitudinal aspect also provides an ability to assess change from one case to the other. The quantitative aspect provides a framework for data collection and analysis. The qualitative aspect informs quantitative data collection by improving the depth of understanding behind the numbers. It also guides and enhances data analysis through the ability to explain interrelationships and variations identified.

RAND developed and tested twenty-five counterinsurgency approaches in Paths to Victory. Based on the RAND findings that there was no correlation between the cultural awareness and redress approaches and the outcome of cases, this research eliminated them from the variables. ${ }^{125}$ Table 1 lists the twenty-three counterinsurgency approaches. Additionally, the Appendix contains a brief definition of each approach and the specific sub-factors that determine the presence of an approach during a phase. In accordance with Paths to Victory, the Appendix

\footnotetext{
${ }^{124}$ Paul et al., Paths to Victory: Lessons from Modern Insurgencies, 16.

${ }^{125}$ Ibid., 127.
} 
also depicts, in parenthesis, the numbers of sub-factors required for the counterinsurgent to implement in order to receive credit for successfully employing that approach. ${ }^{126}$

Table 1. Research Variables

\begin{tabular}{|l|l|l|}
\hline \multicolumn{3}{|c|}{ Approaches } \\
\hline Hearts and Minds & Cost-Benefit & Beat Cop \\
\hline Pacification & Border Control & Boots on the Ground \\
\hline Government Legitimacy & Initiative & Put a Local Face on It \\
\hline Legitimate Use of Force & Crush Them & Commitment and Motivation \\
\hline Reform & Amnesty/Rewards & Tangible Support Reduction \\
\hline Democracy & Strategic Communication & Intelligence \\
\hline Unity of Effort & COIN FM & Flexibility and Adaptability \\
\hline Resettlement & Clear, Hold, Build & \\
\hline
\end{tabular}

Source: Data adapted from Paul et al., Paths to Victory: Lessons from Modern Insurgencies, Table S.1.

\section{Part 2: Case Study Selection}

Since their independence from Britain, India has faced eleven different insurgencies:

communists, Naga, Manipur, Mizo, Tripura, United Liberation Front of Assam, Bodo in Assam, Khalistan movement in Punjab, Sri Lanka, Meghalaya, and Kashmir. ${ }^{127}$ An Indian defense expert asserts that India experienced a pivotal moment in their comprehension of conducting counterinsurgency operations in Sri Lanka. ${ }^{128}$ Therefore, the Sri Lankan expedition provides an excellent intervening case study to compare with counterinsurgency operations against an

${ }^{126}$ Paul et al., Paths to Victory: Lessons from Modern Insurgencies, 86.

${ }^{127}$ Mukherjee, “India's Experiences with Insurgency and Counterinsurgency,” 141; Jonathan Kennedy and Sunil Purushotham, "Beyond Naxalbari: A Comparative Analysis of Maoist Insurgency and Counterinsurgency in Independent India," Comparative Studies in Society and History 54, no. 4 (2012): 833, accessed August 4, 2014, http://dx.doi.org/10.1017/S0010417512000436.

${ }^{128}$ Ashok K. Mehta, "India's Counterinsurgency Campaign in Sri Lanka," in India and Counterinsurgency: Lessons Learned, ed. Sumit Ganguly and David P. Fidler (New York: Routledge, 2009), 156. 
insurgency that occurs both prior to and after Sri Lanka. The other ten insurgencies all occurred within India and serve as potential sources for case selection. However, the Naga and Manipur insurgencies began and culminated prior to the initiation of the Sri Lankan expedition.

Additionally, the Bodo, Khalistan, Meghalaya, and Kashmir insurgencies all began either during or immediately following the Sri Lankan expedition. ${ }^{129}$ These six cases fail to meet the criteria of occurring both prior to the start of operations in Sri Lanka and continuing after India's withdraw. Of the remaining four insurgencies, only the communist insurgency, commonly referred to as the Naxalite insurgency, consists of major operations before and after operations in Sri Lanka.

\section{Part 3: Analysis}

Analysis begins with each individual case study. Understanding changes that occur within each case study serves a secondary purpose of this research to determine under what conditions do militaries demonstrate adaptation. Afterwards, the author conducted a comparison and analysis between both case studies. During the analysis across both case studies, particular attention focuses on the Sri Lanka case study as the intervening variable for this research. Looking at the Naxalite phases prior to and immediately following the Sri Lankan case study provides the data necessary to answer the research question. Using the process tracing methodology discussed by Stephen Van Evera, a political scientist professor and writer, this research attempts to identify whether the Sri Lankan experience caused changes by India in their approach to the Naxalite insurgency. ${ }^{130}$

Four limitations could affect the outcome of this analysis. Based on the fact that only one individual conducted the analysis, there is a possibility that coding errors could occur.

${ }^{129}$ Mukherjee, “India's Experiences with Insurgency and Counterinsurgency,” 141.

${ }^{130}$ Stephen Van Evera, Guide to Methods for Students of Political Science (Ithaca: Cornell University Press, 1997), 56. 
Additionally, this research focuses almost entirely on the actions of the counterinsurgent without similar regards to the actions of the insurgent. Warfare consists of the interaction between two combatants, yet this research design does not account for that interaction. Therefore, this research could discount the actions of the insurgent and negatively affect the outcome. ${ }^{131}$ There is a difference between counterinsurgency and peacekeeping operations. However, this author determined that India's role in Sri Lanka was as a counterinsurgent, not a peacekeeper. ${ }^{132}$ Thus, viewing India’s actions through a counterinsurgency lens rather than a peacekeeping lens could alter the analysis. Lastly, in the attempt to confirm the Sri Lankan experience as the intervening variable, this research may inadvertently miss other contributing variables.

\section{India Peace Keeping Force-Sri Lanka Case Study}

\section{Part 1: Narrative}

There are two foundational reasons leading to India’s decision to get involved in Sri Lanka militarily. The first dates to the sixteenth century with the migration of ethnic Sinhala and Tamil Indians from India to Sri Lanka. ${ }^{133}$ Because of this movement, family connections between Sri Lanka and India were strong. Second, the rise of India as a regional power had a "decisive impact on inter-state relations.” ${ }^{134}$ Specifically, India’s military rise in power from 1947 through 1987 affected state relations. ${ }^{135}$ India’s military growth and power projection capability increased

131 "Nature and Character of War and Warfare."

${ }^{132}$ A peacekeeping force requires both sides to willingly accept their role. In this case, the LTTE did not accept India as a peacekeeping force and continued insurgent activity. Thus, India failed to determine the nature of the war and their role as a counterinsurgent rather than a peacekeeper. 53.

${ }^{133}$ Rajesh Kadian, India's Sri Lanka Fiasco (New Delhi: Vision Books Pvt Ltd, 1990),

${ }^{134}$ P.V.J. Jayasekera, ed., Security Dilemma of a Small State: Sri Lanka in the South Asian Context, Part One (New Delhi: South Asian Publishers Pvt. Ltd., 1992), 424.

135 Ibid., 242. 
to the point that it allowed India to aspire to be the regional hegemon. ${ }^{136}$ India sought to control the region by providing a security blanket for the region at the expense of each state's own foreign policy desires. ${ }^{137}$ India’s desire for regional power, specifically over Sri Lankan affairs, created a series of enduring motives that set the stage for the specific events that triggered India's decision to employ military force.

The origin of issues inside Sri Lanka that prompted India to intervene have their roots in ethnic tensions. Under British rule, the minority Tamil population, who spoke English, dominated the political landscape of Sri Lanka. ${ }^{138}$ After World War British influence waned, the majority Sinhalese population slowly started to implement political reforms in their favor. ${ }^{139}$ The Tamil population rightfully envisioned a diminished role in the future and pushed for regional autonomy. ${ }^{140}$ In 1976, the Tamil population "changed their demands from that of federalism to separatism.” ${ }^{141}$ By 1983, Sri Lankan Tamil's started to receive guerrilla training from the Indian state of Tamil Nadu, the homeland from which most Sri Lankan Tamil’s migrated. ${ }^{142}$ As a result, the Sinhalese dominated Sri Lankan government saw India as destabilizing their population and attempted to align themselves with Western powers. ${ }^{143}$ Their plan failed as India successfully

${ }^{136}$ Jayasekera, Security Dilemma of a Small State: Sri Lanka in the South Asian Context, 483.

${ }^{137}$ Ibid.

${ }^{138}$ Ibid., 507.

${ }^{139}$ Ibid., 508.

${ }^{140}$ Ibid.

${ }^{141}$ Ibid.

142 Ibid.

143 Ibid., 509. 
thwarted their efforts and established themselves as the dominant state. ${ }^{144}$ A series of riots from both ethnic sides within Sri Lanka forced 40,000 Tamils to flee the island and became refugees in Tamil Nadu. ${ }^{145}$ This caused the political leadership within Tamil Nadu to put pressure on the Indian government to intervene on the behalf of the Tamil minority. ${ }^{146}$ After a series of Indiandominated conferences, the two governments signed the Indo-Sri Lankan Accord, leading to Indian intervention on July 29, 1987.

This case study consists of three distinct counterinsurgency phases. The first phase began in July 1987 with the movement of Indian forces into Sri Lanka. ${ }^{147}$ The second phase began in October 1987 when Rajiv Grande, the Indian Prime Minister, ordered a change in the approach for the forces in Sri Lanka. ${ }^{148}$ The third phase began in March of 1989 when India and Sri Lanka informally agreed to withdraw of the IPKF. ${ }^{149}$ Next, India's counterinsurgency approach is broken down by phase. This section ends with an analysis of India's counterinsurgency effectiveness.

\section{Part 2: Phase I}

Article six of the Indo-Sri Lankan Accord stipulated that the Sri Lankan government could request the assistance of the Indian military to quell civil unrest. ${ }^{150}$ The day after signing 509.

${ }^{144}$ Jayasekera, Security Dilemma of a Small State: Sri Lanka in the South Asian Context,

145 Ibid., 521.

146 Ibid., 515.

${ }^{147}$ Kadian, India's Sri Lanka Fiasco, 20.

148 Ibid., 34.

${ }^{149}$ K.M. De Silva, Regional Powers and Small State Security: India and Sri Lanka, 19771990, ed. Professor K. M. De Silva (Baltimore: The Johns Hopkins University Press, 1995), 302.

${ }^{150}$ Kadian, India's Sri Lanka Fiasco, 17. 
the accord, Sri Lanka requested the presence of the Indian military, which deployed immediately to Sri Lanka. ${ }^{151}$ The Indian military and government implemented two counterinsurgency approaches, represented in Table 2, once their military arrived in Sri Lanka.

Table 2. Sri Lanka Phase I

\begin{tabular}{|l|c|}
\hline \multicolumn{1}{|c|}{ Approach } & PH I \\
\hline Hearts and Minds & \\
\hline Pacification & \\
\hline Government Legitimacy & X \\
\hline Legitimate Use of Force & \\
\hline Reform & X \\
\hline Democracy & \\
\hline Unity of Effort & \\
\hline Resettlement & \\
\hline Cost-Benefit & \\
\hline Border Control & \\
\hline Initiative & \\
\hline Crush Them & \\
\hline Amnesty/Rewards & \\
\hline Strategic Communication & \\
\hline COIN FM & \\
\hline Clear, Hold, Build & \\
\hline Beat Cop & \\
\hline Boots on the Ground & \\
\hline Put a Local Face on It & \\
\hline Commitment and Motivation & \\
\hline Tangible Support Reduction & \\
\hline Intelligence & \\
\hline Flexibility and Adaptability & \\
\hline
\end{tabular}

Source: Created by author using approaches extracted from Paul et al., Paths to Victory: Lessons from Modern Insurgencies, Table S.1.

The first approach demonstrated by India was the legitimate use of force. The name of the force India sent to Sri Lanka, the Indian Peace-Keeping Force (IPKF) accurately captured the role envisioned for the forces sent. The IPKF sought to intervene between the Sinhalese security

${ }^{151}$ Kadian, India's Sri Lanka Fiasco, 17. 
forces and the Tamil populations in both the north and east sectors of the island with the goal of allowing the political process to resolve the issues. ${ }^{152}$ Initially, the Tamil population saw the IPKF as a neutral to friendly force and welcomed them as they sought to obtain their political objectives.

At the time, Sri Lanka was a partially functioning, while India was a fully functioning, democracy. The Sri Lankan President, Jayewardene, originally elected in 1977 cancelled the 1983 elections based on the deteriorating security situation and remained in power until the 1988 election. ${ }^{153}$ Therefore, during this phase the government continued to function as partial democracy by extending the previously elected leaders. While the counterinsurgents received credit for being democracies, in reality, the functioning democratic institutions in Sri Lanka represented a legacy Sinhalese dominated government that the Tamils sought to change. Furthermore, India's fully functioning democracy possessed no ability to change conditions within Sri Lanka and was therefore irrelevant in addressing political reconciliation.

The Indian military tried to implement an amnesty/rewards program, but it was limited in scope and therefore unsuccessful. ${ }^{154}$ The program focused solely on weapons turn in without providing an incentive. ${ }^{155}$ As a result, the majority of weapons actually turned in were old,

${ }^{152}$ Gamini Keerawella, “India’s Involvement in the Sri Lankan Ethnic Conflict: Objectives and Modus Operandi 1980-1990,” in Security Dilemma of a Small State: Internal Crisis and External Intervention in Sri Lanka, Part Two., ed. Mahinda Werake and P.V.J. Jayasekera (New Delhi: South Asian Publishers Pvt. Ltd., 1995), 289.

${ }^{153}$ Alan Bullion, India, Sri Lanka and the Tamil Crisis 1976-1994: An International Perspective (London: Cassell Publishers Ltd, 1995), 30.

${ }^{154}$ Kadian, India's Sri Lanka Fiasco, 30.

155 Ibid., 27. 
outdated weapons that the opposition had no use for anymore. ${ }^{156}$ Additionally, it is unclear as to the number of insurgents who actually gave up the fight because of this program.

Another approach attempted by the counterinsurgent force was resettlement. In this case, the Sri Lankan government executed a plan of their own as they moved 50,000 ethnic Sinhalese into Tamil dominated areas. ${ }^{157}$ As identified in the RAND study relocating elements of the population without compensation or improving the quality of life is actually a negative practice. ${ }^{158}$ This one example demonstrates the lack of unity of effort between Sri Lanka and India that plagued this phase of operations. The second example comes from India playing the role of the mediator between the Sri Lankan government and the LTTE. Rather than allow the two organizations to discuss acceptable terms bilaterally, India attempted to force both sides into agreement. However, the gap between the LTTE and the Sri Lankan government was too great as each set of demands was unacceptable to the other side. ${ }^{159}$

\section{Part 3: Phase II}

The first change in approach by India occurred simultaneously with the LTTE leadership dismissing the cease-fire agreement because of a series of events involving LTTE detainees. Concerned about clashes between Sri Lankan forces and the LTTE, India confined Sri Lankan military forces to their barracks. However, the Sri Lankan navy continued operations at sea. Since India never addressed the issue with Sri Lanka, by default, the navy assumed that the confinement to the barracks policy only applied to land forces. As a result, on October 3, 1987, a Sri Lankan

\footnotetext{
${ }^{156}$ Rajagopalan, Fighting Like a Guerrilla: The Indian Army and Counterinsurgency, 92.

${ }^{157}$ Kadian, India's Sri Lanka Fiasco, 29.

158 Paul et al., Paths to Victory: Lessons from Modern Insurgencies, 101.

${ }^{159}$ De Silva, Regional Powers and Small State Security: India and Sri Lanka, 1977-1990,
} 258. 
navy vessel boarded a LTTE ship and arrested seventeen members, including two regional commanders. ${ }^{160}$ The ensuing discussion over the jurisdictional rights of Sri Lanka versus India caused consternation between the two states until India sided with Sri Lanka and allowed them to continue with the detention and prosecution. ${ }^{161}$ Two days later, seventeen LTTE captives committed suicide under Sri Lankan guard rather than remain detainees and await the Sri Lankan judicial process. ${ }^{162}$ At that point, the war took a dramatic change of course. The LTTE began targeting Indian forces based on India’s support for their historical enemy, the Sinhalese dominated Sri Lankan government. Similarly, India recognized that the LTTE was not an organization that could be worked with, labeled them as an enemy, and modified their approach.

The counterinsurgency strategy during this phase included thirteen approaches as represented in Table 3. In the major northern city of Jaffna, the Indian military executed a clear, hold, build approach later modeled by American doctrine. They essentially attempted to remove the LTTE from the city and therefore separate the population from the insurgents. ${ }^{163}$ With Jaffna secured and the LTTE pushed out of the major city, the Indian military pushed a classic hearts and mind strategy throughout Tamil dominated areas and specifically in Jaffna. ${ }^{164}$ Providing security, supporting elections, and rebuilding the infrastructure become the priority in Jaffna. ${ }^{165}$ Additionally, in an effort to sever the LTTE connection with the population, the IPKF pursued

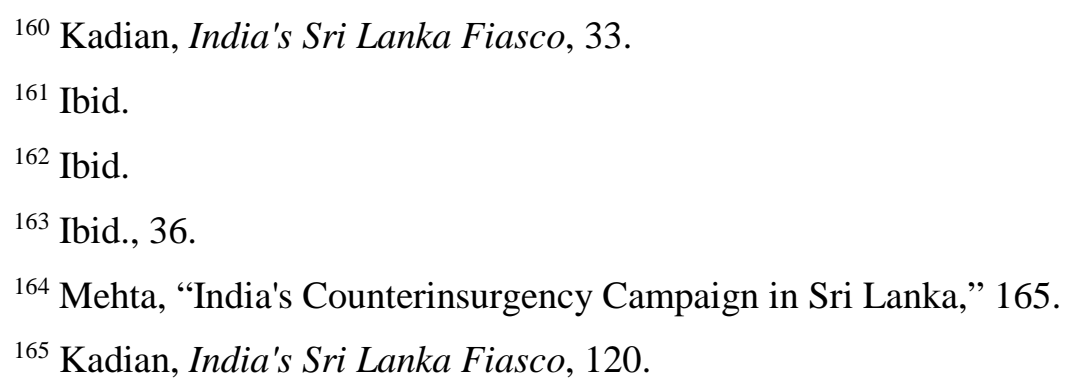


conventional operations aimed at the leadership and specifically at Velupillai Prabhakaran, the LTTE leader. ${ }^{166}$

Table 3. Sri Lanka Phase II

\begin{tabular}{|l|c|c|}
\hline \multicolumn{1}{|c|}{ Approach } & PH I & PH II \\
\hline Hearts and Minds & & X \\
\hline Pacification & & X \\
\hline Government Legitimacy & & \\
\hline Legitimate Use of Force & X & X \\
\hline Reform & & \\
\hline Democracy & X & X \\
\hline Unity of Effort & & \\
\hline Resettlement & & \\
\hline Cost-Benefit & & $\mathrm{X}$ \\
\hline Border Control & & \\
\hline Initiative & & $\mathrm{X}$ \\
\hline Crush Them & & \\
\hline Amnesty/Rewards & & \\
\hline Strategic Communication & & \\
\hline COIN FM & & $\mathrm{X}$ \\
\hline Clear, Hold, Build & & $\mathrm{X}$ \\
\hline Beat Cop & & $\mathrm{X}$ \\
\hline Boots on the Ground & & $\mathrm{X}$ \\
\hline Put a Local Face on It & & \\
\hline Commitment and Motivation & & $\mathrm{X}$ \\
\hline Tangible Support Reduction & & \\
\hline Intelligence & & $\mathrm{X}$ \\
\hline Flexibility and Adaptability & & $\mathrm{X}$ \\
\hline
\end{tabular}

Source: Created by author using approaches extracted from Paul et al., Paths to Victory: Lessons from Modern Insurgencies, Table S.1.

An intelligence-driven kinetic line of effort, typically executed outside of Jaffna, supplemented the co-option and control strategies conducted throughout Indian controlled areas. Operation Checkmate, followed by Operation Mahan Kartavya, isolated the LTTE from the

${ }^{166}$ Kadian, India's Sri Lanka Fiasco, 122. 
population and allowed controversial elections to take place. ${ }^{167}$ Furthermore, within Jaffna, the IPKF attempted to gain the support of the local population by hiring and working with the local Tamil groups, reinstituting rule of law, and removing LTTE influence within Jaffna, which exemplifies the beat cop approach. ${ }^{168}$

With the exception of the battle of Jaffna, the LTTE chose not to engage the Indian military except when conflict was inevitable. ${ }^{169}$ Essentially, they employed a win without losing military strategy. ${ }^{170}$ Instead of focusing on the military aspect to defeat a superior force, the LTTE focused on psychological operations to reduce the morale and support for their opponent while also gathering popular support from ethnic Tamils. ${ }^{171}$ They used improvised explosive devices and anti-personnel mines to frustrate the Indian foot soldiers while simultaneously attacking the Indian narrative for intervention both domestically and internationally. ${ }^{172}$ The LTTE gained and maintained information dominance over the IPKF and this line of effort had a considerable impact on India's decision to withdraw, eventually. ${ }^{173}$

During phase two, the IPKF primarily went about their operations alone. Outside of Jaffna, they weighted their focus on the military aspect of operations in order to allow favorable political conditions to emerge. ${ }^{174}$ Only inside Jaffna, did the IPKF attempt a true hearts and minds

${ }^{167}$ Rajagopalan, Fighting Like a Guerrilla: The Indian Army and Counterinsurgency, 112.

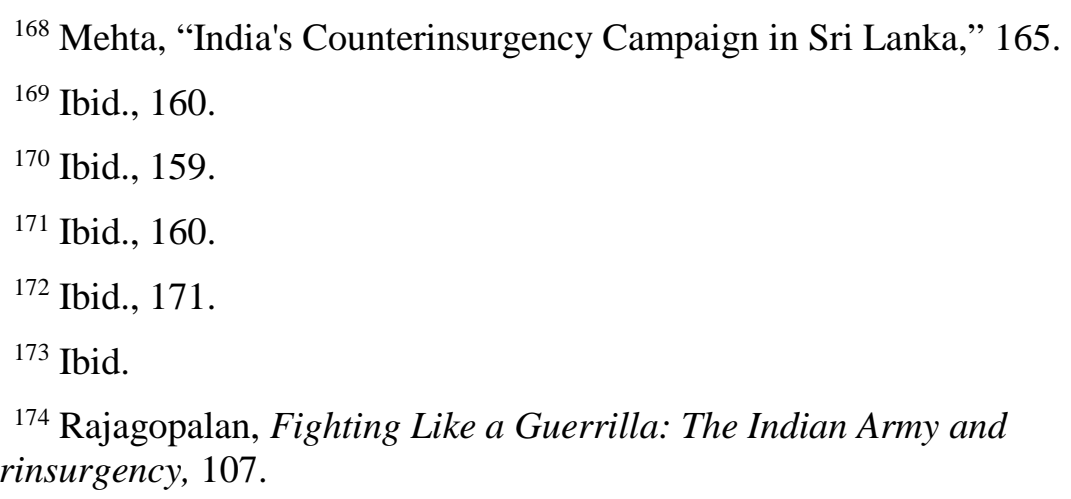


campaign and as a result, the effects of that approach proved minimal. The aggressive military pursuit against the LTTE isolated the insurgents from the population, setting the conditions for elections without the participation of the LTTE. ${ }^{175}$ However, the failure of India and Sri Lanka to implement political reforms into their strategy hampered their ability to resolve any of the key issues.

\section{Part 4: Phase III}

The Sri Lankan elections held in December 1988 ushered in a new president, Premadasa. Premadasa sought to reclaim Sri Lankan legitimacy through the removal of the external force. ${ }^{176}$ Moreover, the LTTE was under enormous military pressure from IPKF operations. ${ }^{177}$ The LTTE lost their hold in major population areas, which effected their ability to influence the population. ${ }^{178}$ Therefore, the LTTE and the new Sri Lankan government cooperated to remove the IPKF from the island as swiftly as possible. ${ }^{179}$ Additionally, V.P. Singh ran for Prime Minister in India on the platform to remove troops from Sri Lanka and won in November of 1989. ${ }^{180}$ These political developments coupled with a growing insurgency along the Pakistan border in Jammu and Kashmir and the loss of Indian domestic support for continued involvement

${ }^{175}$ Rajagopalan, Fighting Like a Guerrilla: The Indian Army and Counterinsurgency, 108.

${ }^{176}$ Kadian, India's Sri Lanka Fiasco, 128.

177 De Silva, Regional Powers and Small State Security: India and Sri Lanka, 1977-1990, 310. 324.

${ }^{178}$ Jayasekera, Security Dilemma of a Small State: Sri Lanka in the South Asian Context,

${ }^{179}$ Bullion, India, Sri Lanka and the Tamil Crisis 1976-1994: An International Perspective, 134.

${ }^{180}$ Mehta, “India's Counterinsurgency Campaign in Sri Lanka,” 167. 
in Sri Lanka prompted the desire to remove the IPKF from Sri Lanka. ${ }^{181}$ In March 1989, Sri Lanka and India came to the initial withdraw agreement, which caused another change of approach used by India. ${ }^{182}$

Depicted in Table 4 are the two operational approach changes made by the IPKF during phase three. India aligned themselves with the Eelam People's Revolutionary Liberation Front (EPRLF), but the EPRLF failed to win the majority of Tamil support. ${ }^{183}$ The EPRLF was a political organization that supported India’s involvement by building paramilitary forces. Following the elections, India sought to bolster the EPRLF, who created four separate forces, through arms and other support as a counter to the LTTE. ${ }^{184}$ Furthermore, to increase the size and capacity of security forces, they also sought the creation of a Citizen Volunteer Force. ${ }^{185}$ Effectively, India sought to put a local face on security using ethnic Tamils. India also demonstrated adaptability and flexibility at the operational level. India built quick reaction teams to deal with the LTTE armed forces who continuously withdrew from battle. ${ }^{186}$ These teams provided increased mobility enabling the IPKF to cut off LTTE withdraw routes and to conduct deep raids into LTTE territory.

${ }^{181}$ Bullion, India, Sri Lanka and the Tamil Crisis 1976-1994: An International Perspective, 137.

${ }^{182}$ De Silva, Regional Powers and Small State Security: India and Sri Lanka, 1977-1990, 302.

${ }^{183}$ Kadian, India's Sri Lanka Fiasco, 128.

184 Ibid., 129.

185 Ibid., 134.

${ }^{186}$ Ibid., 132. 
Table 4. Sri Lanka Phase III

\begin{tabular}{|l|c|c|c|}
\hline \multicolumn{1}{|c|}{ Approach } & PH I & PH II & PH III \\
\hline Hearts and Minds & & X & X \\
\hline Pacification & & X & X \\
\hline Government Legitimacy & & & \\
\hline Legitimate Use of Force & X & X & X \\
\hline Reform & & & \\
\hline Democracy & X & X & X \\
\hline Unity of Effort & & & \\
\hline Resettlement & & & \\
\hline Cost-Benefit & & X & \\
\hline Border Control & & & \\
\hline Initiative & & X & \\
\hline Crush Them & & & \\
\hline Amnesty/Rewards & & & \\
\hline Strategic Communication & & X & \\
\hline COIN FM & & X & \\
\hline Clear, Hold, Build & & X & \\
\hline Beat Cop & & X & \\
\hline Boots on the Ground & & \\
\hline Put a Local Face on It & & X & \\
\hline Commitment and Motivation & & & \\
\hline Tangible Support Reduction & & $\mathrm{X}$ & \\
\hline Intelligence & & \\
\hline Flexibility and Adaptability & & \\
\hline
\end{tabular}

Source: Created by author using approaches extracted from Paul et al., Paths to Victory: Lessons from Modern Insurgencies, Table S.1.

Multiple problems existed with India’s conduct of counterinsurgency during phase three.

The lack of unity of effort by both governments, both militaries, and between civilian and military interactions was one of the most glaring issues. The Sri Lankan government was equally concerned about dealing with another insurgency in the south. ${ }^{187}$ Some tactical level commanders

${ }^{187}$ De Silva, Regional Powers and Small State Security: India and Sri Lanka, 1977-1990, 299. The Jonatha Vimukthi Peramuna (JVP) was a violent Sinhalese insurgency using Maoist ideology to overthrow the current Sri Lankan government because they allowed India's military forces to intervene in a domestic affair. 
entered into agreements with the LTTE to avoid confrontation. ${ }^{188}$ Additionally, the EPRLF was not the dominant Tamil organization at the time. While India supported them, the ethnic Tamil population favored other groups, such as the Eelam Revolutionary Organization of Students, who won the majority of positions in the national elections. ${ }^{189}$ Finally, Indian officer positions went unfilled over time as the Kashmir insurgency started in July of 1988 and became a more important security concern for India. ${ }^{190}$

\section{Part 5: Conclusion}

Using Table 4 as a reference, the counterinsurgency strategy was clearly lacking in many regards. At the outset of the conflict, there was a misinterpretation of the nature of the conflict and thus the India employed mostly a policing rather than a counterinsurgency effort. Secondly, the IPKF implemented a number of efforts in phase two to quell the insurgents while simultaneously gaining support from the population. A possible explanation for the abrupt transition in this phase may link to the change in motivation and commitment on the part of India. Similarly, the decreased level of commitment in the third phase may also explain the reduction of efforts by India. Third, failing to target and the inability to reduce the tangible support for the LTTE allowed the insurgents to survive and continue the fight in each phase, to include after the Indian military withdrew from the island. In line with one of the key findings highlighted in Paths to Victory, the lack of tangible support reduction by the counterinsurgent directly correlates to a counterinsurgent loss. ${ }^{191}$ The absence of unity of effort provides the best possible explanation as to why the counterinsurgents did not focus on support reduction. Sri Lanka and India saw vastly

\footnotetext{
${ }^{188}$ Kadian, India's Sri Lanka Fiasco, 132.

${ }^{189}$ Ibid., 128.

${ }^{190}$ Ibid., 132.

${ }^{191}$ Paul et al., Paths to Victory: Lessons from Modern Insurgencies, xxiii.
} 
different endings to the same conflict and therefore coordinating efforts became extremely difficult and for the most part non-existent. Additionally, even within India there was a lack of coordination between government agencies. ${ }^{192}$ India’s Research and Analysis Wing funded and trained the LTTE starting in 1982, but they shared little to no information with the IPKF. 193 Fourth, only two approaches implemented in phase two carried over into phase three: hearts and minds and pacification. The most likely explanation for this occurrence was the desire for India to appear as though they were not abandoning the Tamil population. With India's government seeking a face saving way out and Sri Lanka's desire to remove the external force from their internal affairs, the two sides toiled through four months of tough negotiations until India finally removed all troops. ${ }^{194}$

\section{Naxalite Case Study \\ Part 1: Narrative}

India’s Naxalite insurgency traces its lineage back to the 1940s. Their ideology forms its base around communism, while the Naxalite strategy to achieve communism envisions the use of Mao’s theory of revolution. ${ }^{195}$ The Naxalites therefore sought to build a base of support from which they could project guerilla war onto their opponent and eventually defeat the Indian government militarily. ${ }^{196}$ Originating in the 1940s, the insurgency was known as a communist

\footnotetext{
192 Mehta, “India's Counterinsurgency Campaign in Sri Lanka,” 169.

${ }^{193}$ Marks, "Counterinsurgency and Operational Art," 176.

${ }^{194}$ De Silva, Regional Powers and Small State Security: India and Sri Lanka, 1977-1990,
} 311-315.

${ }^{195}$ Kennedy and Purushotham, "Beyond Naxalbari: A Comparative Analysis of Maoist Insurgency and Counterinsurgency in Independent India," 832.

196 "Problems of Strategy in China's Revolutionary War," Selected Works from Mao TseDong, 2004, accessed December 9, 2014, http://www.marxists.org/reference/archive/mao/selected-works/volume-1/mswv1_12.htm. 
uprising and it was not until the late 1960s that they received the Naxalite name. ${ }^{197}$ The word Naxalite comes from Naxalbari, a geographical region located in West Bengal where the second communist uprising began. ${ }^{198}$ Even though an earlier uprising began under a different name, this research uses the term Naxalites throughout to maintain continuity.

Three constants allowed this insurgency to last nearly seven decades. In all phases, the Naxalites exploited the divide between the poor agrarian population and the rich population. ${ }^{199}$ The rich population included the landowners and the government that allows for the continuation of the status quo. The Naxalite population endures elite rule and suffers from extreme poverty. ${ }^{200}$ The roots of this exploitation trace back to the British Colonial period where large property owners sought to produce the maximum amount possible from the land to sell to the East India Company. ${ }^{201}$ Property owners enslaved the workers through high taxes that entrenched the workers with no alternative options. ${ }^{202}$ India's inability to enact land reform legislation or enforce one served as the constant reminder that only the Naxalites looked to solve the issues for the peasant farmers. ${ }^{203}$ The Naxalites envisioned land reform to fix this economic inequality and appealed to poor farmers by implementing their own reforms. ${ }^{204}$ This allowed the Naxalite

${ }^{197}$ Kennedy and Purushotham, "Beyond Naxalbari: A Comparative Analysis of Maoist Insurgency and Counterinsurgency in Independent India," 833.

198 Ibid.

${ }^{199}$ Pratul Ahuja and Rajat Ganguly, "The Fire Within: Naxalite Insurgency Violence in India," Small Wars and Insurgencies 18, no. 2 (06 Dec 2007): 249, accessed August 4, 2014, http://dx.doi.org/10.1080/09592310701400861.

${ }^{200}$ Ibid.

${ }^{201}$ Ibid., 254.

202 Ibid.

${ }^{203}$ John Harriss, "What is going on in India's 'red corridor'? Questions about India's Maoist insurgency,” Pacific Affairs 84, no. 2 (June 2011): 316.

${ }^{204}$ Ibid., 318. 
insurgency to survive in locations that provide inaccessible terrain to government forces. ${ }^{205}$ As a result, the presence of the Naxalites ideology occurred where government control was weak and the terrain favored guerrilla operations. ${ }^{206}$

The Naxalite case study breaks down into five separate counterinsurgency phases based on changes made to the counterinsurgency approach utilized by India. The first phase starts in 1948 when India undertook operations to counter the Communist Party of India (CPI), who attempted to gain political control after India gained independence from Britain. The second phase began in 1951 when India stopped military operations and returned to state led governance and enforcement. India initiated the third phase in 1967 with negotiations and police operations targeting forces located in Naxalbari. The fourth phase outlines another dormant phase of counterinsurgency operations that began in 1972 and lasted until 2005. The fifth counterinsurgency phase began with the resumption of operations against the Naxalites in 2005 and currently persists.

\section{Part 2: Phase I}

Decolonization from Britain provided each Indian state the opportunity to forge their own path to independence. Initially, the Nizam monarchy, who ruled the state of Andhra Pradesh, chose not to join the India Union as the rest of the Indian states choose to do. ${ }^{207}$ The reason this became such an issue was that the Nizam regime was predominately of Muslim faith while the rest of India was Hindu. ${ }^{208}$ Coupled with the fact that Britain had granted Pakistan its own

${ }^{205}$ Kennedy and Purushotham, "Beyond Naxalbari: A Comparative Analysis of Maoist Insurgency and Counterinsurgency in Independent India," 852.

206 Ibid.

${ }^{207}$ Ibid., 838.

${ }^{208}$ Michael Edwardes, Nehru, a Political Biography (New York: Praeger Publishers, 1972), 222. 
separate independence, India feared that a state located in the center of India aligned with

Pakistan was a great threat to their security. As a result, the Indian Union imposed a blockade on Andhra Pradesh and, coupled with widespread manufacturing strikes, student protests, and cross border raids from neighboring states, the Nizam government ceased to exist in rural Telengana. ${ }^{209}$ In the wake of the power vacuum left behind, the Naxalites consolidated administrative control over the Telengana area and instituted a series of reforms to include land reform to secure their base of support. ${ }^{210}$ The Indian Army invaded the state in September 1948 to completely remove the ineffective Nizam government, enter the state to the Indian Union, and reestablish governance throughout the state. ${ }^{211}$ The communist insurgency in Telengana proved to be one of the more challenging aspects of restoring governance throughout the state as they sought to establish their own form of government.

Using Table 5 as a reference, the operational approach employed by the India Army included establishing legitimacy by forcing Andhra Pradesh into the Indian Union. This effort alone fractured the support for the communists as it provided validity to the military's presence and met the desires of the population. ${ }^{212}$ Additionally, it halted cross border raids from neighboring states, who sought to undermine the previous regime. It also prevented the Nizam regime and the Naxalite insurgency from receiving external assistance. ${ }^{213}$ A separate line of effort

${ }^{209}$ Kennedy and Purushotham, "Beyond Naxalbari: A Comparative Analysis of Maoist Insurgency and Counterinsurgency in Independent India," 838.

${ }^{210}$ Ibid.

${ }^{211}$ Michael Edwardes, Nehru, a Political Biography, 225. By the time India intervened, the Nizam government was controlled by its own Muslim militia called the Razakhars.

${ }^{212}$ Kennedy and Purushotham, "Beyond Naxalbari: A Comparative Analysis of Maoist Insurgency and Counterinsurgency in Independent India," 838.

${ }^{213}$ Ibid. 
was securing the population through the buildup of local security forces. ${ }^{214}$ The home guards, village defense squads, and the Grama Raksha Dals eventually became additional police units assisting with the security situation. ${ }^{215}$ Furthermore, these units obtained critical intelligence to target the opposition and foil enemy plans. ${ }^{216}$ As the push continued into enemy controlled territory, the access to intelligence diminished and the actions of the military became repressive in an attempt to crush the rebellion. ${ }^{217}$ Behind the army’s push, the Indian government implemented a strong development campaign aimed at winning over the people. ${ }^{218}$ The last element implemented by India during this phase was the selective resettlement of the population out of the densely forested areas into government-controlled camps. ${ }^{219}$

${ }^{214}$ Kennedy and Purushotham, "Beyond Naxalbari: A Comparative Analysis of Maoist Insurgency and Counterinsurgency in Independent India," 843.

${ }^{215}$ Ibid.

${ }^{216}$ Ibid., 838.

${ }^{217}$ Ibid., 839.

${ }^{218}$ Ibid., 842.

${ }^{219}$ Ibid., 843. 
Table 5. Naxalite Phase I

\begin{tabular}{|l|c|}
\hline \multicolumn{1}{|c|}{ Approach } & PH I \\
\hline Hearts and Minds & $\mathrm{X}$ \\
\hline Pacification & $\mathrm{X}$ \\
\hline Government Legitimacy & $\mathrm{X}$ \\
\hline Legitimate Use of Force & $\mathrm{X}$ \\
\hline Reform & \\
\hline Democracy & $\mathrm{X}$ \\
\hline Unity of Effort & $\mathrm{X}$ \\
\hline Resettlement & \\
\hline Cost-Benefit & $\mathrm{X}$ \\
\hline Border Control & $\mathrm{X}$ \\
\hline Initiative & $\mathrm{X}$ \\
\hline Crush Them & $\mathrm{X}$ \\
\hline Amnesty/Rewards & \\
\hline Strategic Communication & \\
\hline COIN FM & $\mathrm{X}$ \\
\hline Clear, Hold, Build & $\mathrm{X}$ \\
\hline Beat Cop & $\mathrm{X}$ \\
\hline Boots on the Ground & $\mathrm{X}$ \\
\hline Put a Local Face on It & $\mathrm{X}$ \\
\hline Commitment and Motivation & $\mathrm{X}$ \\
\hline Tangible Support Reduction & $\mathrm{X}$ \\
\hline Intelligence & $\mathrm{X}$ \\
\hline Flexibility and Adaptability & $\mathrm{X}$ \\
\hline
\end{tabular}

Source: Created by author using approaches extracted from Paul et al., Paths to Victory: Lessons from Modern Insurgencies, Table S.1.

\section{$\underline{\text { Part 3: Phase II }}$}

At the end of 1951, India perceived success and therefore ended all counterinsurgency operations. This marked the transition from phase one to two against the Naxalites. India sought to consolidate their gains through the return to normal state governmental control. As depicted in Table 6, phase two was marked less by counterinsurgent approaches and more by the absence of them based on the CPI decision to join the political process. As a result, India only implemented a few approaches. The primary effort focused on combating the insurgency through the democratic 
process. In the mid to late 1950s, the government passed land reforms in favor of the peasant sharecropper. ${ }^{220}$ The government demonstrated resolve, flexibility, and unity of effort by aligning all government agencies behind the political process. However, in reality there was no change as the landowners maintained their dominance and the government unsuccessfully implemented the reforms. ${ }^{221}$

${ }^{220}$ Ahuja and Ganguly, "The Fire Within: Naxalite Insurgency Violence in India," 255.

${ }^{221}$ Kennedy and Purushotham, "Beyond Naxalbari: A Comparative Analysis of Maoist Insurgency and Counterinsurgency in Independent India," 845. 
Table 6. Naxalite Phase II

\begin{tabular}{|l|c|c|}
\hline \multicolumn{1}{|c|}{ Approach } & PH I & PH II \\
\hline Hearts and Minds & $\mathrm{X}$ & \\
\hline Pacification & $\mathrm{X}$ & \\
\hline Government Legitimacy & $\mathrm{X}$ & $\mathrm{X}$ \\
\hline Legitimate Use of Force & $\mathrm{X}$ & \\
\hline Reform & & \\
\hline Democracy & $\mathrm{X}$ & $\mathrm{X}$ \\
\hline Unity of Effort & $\mathrm{X}$ & $\mathrm{X}$ \\
\hline Resettlement & & \\
\hline Cost-Benefit & $\mathrm{X}$ & \\
\hline Border Control & $\mathrm{X}$ & \\
\hline Initiative & $\mathrm{X}$ & \\
\hline Crush Them & $\mathrm{X}$ & \\
\hline Amnesty/Rewards & & \\
\hline Strategic Communication & & \\
\hline COIN FM & $\mathrm{X}$ & \\
\hline Clear, Hold, Build & $\mathrm{X}$ & \\
\hline Beat Cop & $\mathrm{X}$ & \\
\hline Boots on the Ground & $\mathrm{X}$ & \\
\hline Put a Local Face on It & $\mathrm{X}$ & \\
\hline Commitment and Motivation & $\mathrm{X}$ & $\mathrm{X}$ \\
\hline Tangible Support Reduction & $\mathrm{X}$ & \\
\hline Intelligence & $\mathrm{X}$ & \\
\hline Flexibility and Adaptability & $\mathrm{X}$ & $\mathrm{X}$ \\
\hline
\end{tabular}

Source: Created by author using approaches extracted from Paul et al., Paths to Victory: Lessons from Modern Insurgencies, Table S.1.

The CPI failed to have an impact during the first three election. Seeing no results through either elections or reforms, the CPI fractured into those who wanted to continue working within the system and those who did not. ${ }^{222}$ Thus, the Communist Party of India-Marxist (CPI-M) came into being. Although initially formed to avoid the political process, the CPI-M reluctantly embraced the political process. Then at the onset of the 1965 Indo-Pakistan War, the CPI-M

${ }^{222}$ Keith J. Harnetiaux, "The Resurgence of Naxalism: How Great a Threat to India" (master's thesis, Naval Postgraduate School, 2008), 13. 
condemned their historical rivals, Pakistan and China. ${ }^{223}$ This move allowed them to ride an Indian wave of nationalism surrounding the event and during the 1967 election the CPI-M fully entrenched themselves through elections into the Indian government. ${ }^{224}$ Unfortunately, embracing the political process caused another split, this time from the CPI-M, which founded the Communist Party of India-Marxist Leninist (CPI-LM). ${ }^{225}$ The CPI-LM espoused the original views established during phase one. Only through violent revolution could the CPI-LM achieve their aims. ${ }^{226}$ The CPI-LM, who would eventually be renamed the Naxalites started building the foundation for the upcoming revolution.

\section{Part 4: Phase III}

While the Naxalites reorganized, a number of other events occurred, which contributed to the re-initiation of hostilities. First, in 1967, India experienced a countrywide famine that caused the government to acquire and distribute large amounts of food to the population. ${ }^{227}$ Widespread corruption by the government and local elites prevented adequate distribution, which caused an already unsatisfied minority to seek organization and assistance. The Naxalites provided that organization and timed their first armed actions in March 1967 to coincide with the inauguration of the United Front Indian government. ${ }^{228}$ Over the next two years, the Naxalites attempted to consolidate their power in Naxalbari by occupying land, controlling the harvest, destroying land

${ }^{223}$ Keith J. Harnetiaux, "The Resurgence of Naxalism: How Great a Threat to India" (master's thesis, Naval Postgraduate School, 2008), 13.

224 Ibid.

225 Ibid.

${ }^{226}$ Ibid., 14.

${ }^{227}$ Ahuja and Ganguly, "The Fire Within: Naxalite Insurgency Violence in India," 254.

${ }^{228}$ Kennedy and Purushotham, "Beyond Naxalbari: A Comparative Analysis of Maoist Insurgency and Counterinsurgency in Independent India," 846. 
records, cancelling peasant debts owed to the elite, and distributing death sentences to property owners. ${ }^{229}$ The Indian Government attempted to negotiate with the Naxalbari insurgency, but when the talks failed in late 1967, the government initiated a series of actions, which marked the initiation of phase three.

By 1969, India had massed its military in West Bengal based on the Bangladesh war of independence against Pakistan. ${ }^{230}$ Seeing little results from previous actions prompted India to take advantage of the massive military forces sitting in close proximity and initiated Operation Steeplechase. ${ }^{231}$ During July and August of 1971, Operation Steeplechase imprisoned over 20,000 suspected Naxalites, including leadership, and killed hundreds more. ${ }^{232}$ With the insurgency defeated in Naxalbari, the government turned its attention to other areas of the country that exhibited the same types of threats. Table 7 represents the approaches implemented by India during phase three. India’s approach varied slightly depending on the geographical location, which means the table represents a compilation of approaches used throughout India.

${ }^{229}$ Kennedy and Purushotham, "Beyond Naxalbari: A Comparative Analysis of Maoist Insurgency and Counterinsurgency in Independent India," 846.

${ }^{230}$ Anup K. Palhari, “Unequal Rebellions: The continuum of ”Peoples War“ in Nepal and India," in The Maoist Insurgency in Nepal: Revolution in the Twenty-First Century, ed. Mahendra Lawoti and Anup K. Pahari (New York: Routledge, 2010), 208, accessed February 5, 2015, https://books.google.com/books?id=KtGNAgAAQBAJ\&pg=PR10\&lpg=PR10\&dq=Part+V:+Mil itary+and+state+dimension. +The+Maoist+Insurgency+in+Nepal:+Revolution+in+the+Twentyfirst+Century.\&source=bl\&ots=sC_gXEMxeK\&sig=lw9wYS4NBxkrOqWbcaOtPmjz7g\&hl=en\&sa=X\&ei=4JfTVO-.

${ }^{231}$ Ibid.

${ }^{232}$ Ibid. 
Table 7. Naxalite Phase III

\begin{tabular}{|l|c|c|c|}
\hline \multicolumn{1}{|c|}{ Approach } & PH I & PH II & PH III \\
\hline Hearts and Minds & $\mathrm{X}$ & & \\
\hline Pacification & $\mathrm{X}$ & & $\mathrm{X}$ \\
\hline Government Legitimacy & $\mathrm{X}$ & $\mathrm{X}$ & $\mathrm{X}$ \\
\hline Legitimate Use of Force & $\mathrm{X}$ & & $\mathrm{X}$ \\
\hline Reform & & & \\
\hline Democracy & $\mathrm{X}$ & $\mathrm{X}$ & $\mathrm{X}$ \\
\hline Unity of Effort & $\mathrm{X}$ & $\mathrm{X}$ & $\mathrm{X}$ \\
\hline Resettlement & & & \\
\hline Cost-Benefit & $\mathrm{X}$ & & $\mathrm{X}$ \\
\hline Border Control & $\mathrm{X}$ & & $\mathrm{X}$ \\
\hline Initiative & $\mathrm{X}$ & & $\mathrm{X}$ \\
\hline Crush Them & $\mathrm{X}$ & & $\mathrm{X}$ \\
\hline Amnesty/Rewards & & & $\mathrm{X}$ \\
\hline Strategic Communication & & & $\mathrm{X}$ \\
\hline COIN FM & $\mathrm{X}$ & & $\mathrm{X}$ \\
\hline Clear, Hold, Build & $\mathrm{X}$ & & $\mathrm{X}$ \\
\hline Beat Cop & $\mathrm{X}$ & & $\mathrm{X}$ \\
\hline Boots on the Ground & $\mathrm{X}$ & & $\mathrm{X}$ \\
\hline Put a Local Face on It & $\mathrm{X}$ & & $\mathrm{X}$ \\
\hline Commitment and Motivation & $\mathrm{X}$ & $\mathrm{X}$ & $\mathrm{X}$ \\
\hline Tangible Support Reduction & $\mathrm{X}$ & & $\mathrm{X}$ \\
\hline Intelligence & $\mathrm{X}$ & & $\mathrm{X}$ \\
\hline Flexibility and Adaptability & $\mathrm{X}$ & $\mathrm{X}$ & $\mathrm{X}$ \\
\hline
\end{tabular}

Source: Created by author using approaches extracted from Paul et al., Paths to Victory: Lessons from Modern Insurgencies, Table S.1.

Insurgent activity thrived in three areas and required a governmental response: West Bengal; Srikakulam, Andhra Pradesh; and Telengana, Andhra Pradesh. Similar to phase one, once police action became ineffective to defeat the insurgency, India sent paramilitary forces or the 
Army. ${ }^{233}$ India supplemented these forces through the co-option of insurgents by employing them in local security organizations. ${ }^{234}$ This increased intelligence gathering for Indian forces, which allowed them to target insurgent support and leadership, effectively. These additional forces also allowed India to backfill secure areas with forces in order to free up additional combat power to continue the push into insurgent controlled areas. These clear and hold operations successfully rooted out the poorly led and organized insurgency. ${ }^{235}$ Combining these approaches with the use of both repression and a resettlement plan effectively rooted out the insurgents in all areas except Telengana. ${ }^{236}$ The insurgency in the sparsely populated and guerrilla friendly terrain of the forested region of Telengana survived again although it was severely weakened. ${ }^{237}$

Diplomatic efforts complimented these military operations in all three areas. These diplomatic efforts essentially pacified the rural population, which undercut the Naxalite base of support. ${ }^{238}$ Additionally, the government benefited from the CPI's growing support within the communist community of India. The CPI advocated that reforms would occur through the Indian political process and thus supported the government of India's position. This effort was so effective that the CPI doubled their seats in the government from 1967-1969 and then increased that number by another twenty-five percent during the 1971 election. ${ }^{239}$ Another significant

${ }^{233}$ Jennifer L. Oetken, “Counterinsurgency against Naxalites in India,” in India and Counterinsurgency: Lessons Learned, ed. Sumit Ganguly and David P. Fidler (New York: Routledge, 2009), 133.

${ }^{234}$ Kennedy and Purushotham, "Beyond Naxalbari: A Comparative Analysis of Maoist Insurgency and Counterinsurgency in Independent India," 850.

${ }^{235}$ Oetken, “Counterinsurgency against Naxalites in India,” 135.

${ }^{236}$ Kennedy and Purushotham, "Beyond Naxalbari: A Comparative Analysis of Maoist Insurgency and Counterinsurgency in Independent India," 849.

${ }^{237}$ Ibid.

${ }^{238}$ Ibid.

239 Ibid. 
contributing factor during this phase was the political platform that Indira Gandhi, who ran for and won the 1971 prime minister election. ${ }^{240}$ Her slogan during that campaign was "get rid of poverty” and it had a tremendous impact on the population as represented by winning seventyfive percent of the vote in $1971 .{ }^{241}$ Similarly, the CPI firmly cemented themselves into the government during the 1971 elections, which allowed the Indian government to stop counterinsurgency operations and return to state led governance and internal security.

\section{Part 5: Phase IV}

The fourth phase began in 1972, with the return to normal governance across India. Normalcy lasted until July 1975 when Indira Gandhi declared a state of emergency across India to quell a possible political revolution. ${ }^{242}$ For two years, the government of Naxalbari used the powers provided by the state of emergency proclamation to crack down on the Naxalites. ${ }^{243}$ As a result, the police arrested approximately 25,000 citizens, Naxalites and non-Naxalites alike. ${ }^{244}$ In 1977, the government ended the state of emergency and both the national and state governments turned their attention away from the Naxalite movement. This decision provided the space for the Naxalites to increase the amount of external support over the coming decades. "The ability to procure sophisticated weapons and ammunition as well as guerrilla warfare training from various

${ }^{240}$ Kennedy and Purushotham, "Beyond Naxalbari: A Comparative Analysis of Maoist Insurgency and Counterinsurgency in Independent India," 849.

${ }^{241}$ Ibid.

${ }^{242}$ Barbara D. Metcalf and Thomas R. Metcalf, A Concise History of Modern India, 2nd ed. (Cambridge: Cambridge University Press, 2006), 255. Shortly after being elected, Indira Gandhi was accused of abusing funds and other election related fraud. After four years, she was acquitted of the charges. Her opposition attempted to mobilize the state by calling for a massive revolution, which prompted Indira Gandhi to proclaim a state of emergency. This allowed Indira Gandhi to use force to silence and imprison the opposition. 208.

${ }^{243}$ Palhari, “Unequal Rebellions: The continuum of 'Peoples War' in Nepal and India,” ${ }^{244}$ Ibid. 
regional terrorist groups allowed the various Naxalite groups to carry out violent attacks against the state” during phase five. ${ }^{245}$

Illustrated in Table 8 are the six counterinsurgent approaches utilized by India during phase four. The counterinsurgent primarily attempted to bring opposition groups into the democratic process. However, the state of emergency provided a two-year period for the state government to apply repressive measures on the Naxalites and the population as a whole. Similar to the internal splits that occurred in phase two, phase four also saw the emergence of new communists groups, some of whom joined the political process and others whom sought revolution. The Peoples War Group (PWG) was founded in 1980 by K. Seetharamaiah, who fought in both phase one and three in the Telengana district of Andhra Pradesh. ${ }^{246}$ The second important group that emerged during this phase was the Maoist Communist Centre, who arose in the state of Bihar. Both communist groups pursued the same Maoist strategy of consolidating their base of support with the poor rural population while enacting local administration to provide themselves legitimacy. ${ }^{247}$

While these groups sought to reconstitute the insurgency, India pursued the same democratic strategy with known communist groups and in the case of the CPI-M found a willing and able partner. The CPI-M won the 1977 West Bengal elections and maintained their party's power for the entire phase by not only passing land reform, but also enforcing it. ${ }^{248}$ During the early 1980s, the government did attempt two different development reform programs: the

${ }^{245}$ Ahuja and Ganguly, "The Fire Within: Naxalite Insurgency Violence in India," 264.

${ }^{246}$ Oetken, “Counterinsurgency against Naxalites in India,” 136.

${ }^{247}$ Kennedy and Purushotham, "Beyond Naxalbari: A Comparative Analysis of Maoist Insurgency and Counterinsurgency in Independent India," 851.

${ }^{248}$ Ibid. 
Integrated Rural Development Programme and the Indira Housing Scheme. ${ }^{249}$ Both programs advocated the desire to improve the quality of life for the rural peasants. However, due to governmental corruption, unavailability of land, and the fact that the peasant did not have enough money to initiate the process contributed to both efforts failing. ${ }^{250}$ Failing to address the grievances politically and the removal of military/police pressure provided space for the Naxalite movements to gain momentum. ${ }^{251}$

${ }^{249}$ Ahuja and Ganguly, "The Fire Within: Naxalite Insurgency Violence in India," 258.

250 Ibid.

${ }^{251}$ Oetken, “Counterinsurgency against Naxalites in India,” 142. 
Table 8. Naxalite Phase IV

\begin{tabular}{|l|c|c|c|c|}
\hline \multicolumn{1}{|c|}{ Approach } & PH I & PH II & PH III & PH IV \\
\hline Hearts and Minds & X & & & \\
\hline Pacification & X & & X & \\
\hline Government Legitimacy & $\mathrm{X}$ & $\mathrm{X}$ & $\mathrm{X}$ & $\mathrm{X}$ \\
\hline Legitimate Use of Force & $\mathrm{X}$ & & $\mathrm{X}$ & \\
\hline Reform & & & & \\
\hline Democracy & $\mathrm{X}$ & $\mathrm{X}$ & $\mathrm{X}$ & $\mathrm{X}$ \\
\hline Unity of Effort & $\mathrm{X}$ & $\mathrm{X}$ & $\mathrm{X}$ & $\mathrm{X}$ \\
\hline Resettlement & & & & \\
\hline Cost-Benefit & $\mathrm{X}$ & & $\mathrm{X}$ & \\
\hline Border Control & $\mathrm{X}$ & & $\mathrm{X}$ & \\
\hline Initiative & $\mathrm{X}$ & & $\mathrm{X}$ & \\
\hline Crush Them & $\mathrm{X}$ & & $\mathrm{X}$ & $\mathrm{X}$ \\
\hline Amnesty/Rewards & & & $\mathrm{X}$ & \\
\hline Strategic Communication & & & $\mathrm{X}$ & \\
\hline COIN FM & $\mathrm{X}$ & & $\mathrm{X}$ & \\
\hline Clear, Hold, Build & $\mathrm{X}$ & & $\mathrm{X}$ & \\
\hline Beat Cop & $\mathrm{X}$ & & $\mathrm{X}$ & \\
\hline Boots on the Ground & $\mathrm{X}$ & & $\mathrm{X}$ & \\
\hline Put a Local Face on It & $\mathrm{X}$ & & $\mathrm{X}$ & \\
\hline Commitment and Motivation & $\mathrm{X}$ & $\mathrm{X}$ & $\mathrm{X}$ & $\mathrm{X}$ \\
\hline Tangible Support Reduction & $\mathrm{X}$ & & $\mathrm{X}$ & \\
\hline Intelligence & $\mathrm{X}$ & & $\mathrm{X}$ & \\
\hline Flexibility and Adaptability & $\mathrm{X}$ & $\mathrm{X}$ & $\mathrm{X}$ & $\mathrm{X}$ \\
\hline
\end{tabular}

Source: Created by author using approaches extracted from Paul et al., Paths to Victory: Lessons from Modern Insurgencies, Table S.1.

\section{Part 6: Phase V}

The combination of the PWG and the Maoist Communist Centre to form the Communist Party of India-Maoist (CPI-Maoist) in 2004 signified the coming change of insurgent strategy and within a year, India answered with a new counterinsurgency strategy. This phase saw insurgent activity in Bihar, Jharkhand, Chhattisgarh, West Bengal, Orissa, and Andra Pradesh. During this phase, India implemented eighteen counterinsurgent approaches. Again, approaches varied by location based on India's desire to allow states to determine the most effective course for their problem set. India used locally recruited police forces to assist with intelligence and security 
functions. ${ }^{252}$ The most successful use occurred in Andhra Pradesh, where the establishment of a trained local counterguerrilla force, called the Greyhound Force, effectively opposed the Naxalites. ${ }^{253}$ Some, like the Salwa Judum, operate in Chhattisgarh with little regard for the differentiation between active Naxalite combatants, active or passive supporters, and civilians living in the 'wrong area. ${ }^{254}$ Additionally, they also reinstituted resettlement activities to control portions of the population. ${ }^{255}$ India also attacked insurgent strongholds and implemented a clear, hold, build strategy that mirrors elements found in US counterinsurgency doctrine. ${ }^{256}$ Operation Green Hunt was a massive search and destroy operation to remove insurgent strongholds in mostly inaccessible terrain. ${ }^{257}$ India also increased the number of security personnel. This increase improved the ratio between the number of counterinsurgent forces, insurgents, and the local population. Table 9 reflects the eighteen approaches used by India during phase five.

252 Jason Miklian, "The Purification Hunt: The Salwa Judum Counterinsurgency in Chhattisgarh, India," Dialect Anthropol 33 (27 October 2009): 445.

${ }^{253}$ Sameer Lalwani, "India's Approach to Counterinsurgency and the Naxalite Problem," CTC Sentinel 4, no. 10 (October 2011): 8, accessed August 5, 2014, https://www.ctc.usma.edu/posts/india's-approach-to-counterinsurgency-and-the-naxalite-problem.

${ }^{254}$ Miklian, "The Purification Hunt: The Salwa Judum Counterinsurgency in Chhattisgarh, India," 451.

${ }^{255}$ Kennedy and Purushotham, "Beyond Naxalbari: A Comparative Analysis of Maoist Insurgency and Counterinsurgency in Independent India," 855.

${ }^{256}$ Ibid., 856.

${ }^{257}$ Lalwani, "India's Approach to Counterinsurgency and the Naxalite Problem," 7. 
Table 9. Naxalite Phase V

\begin{tabular}{|l|c|c|c|c|c|}
\hline \multicolumn{1}{|c|}{ Approach } & PH I & PH II & PH III & PH IV & PH V \\
\hline Hearts and Minds & $\mathrm{X}$ & & & & \\
\hline Pacification & $\mathrm{X}$ & & $\mathrm{X}$ & & $\mathrm{X}$ \\
\hline Government Legitimacy & $\mathrm{X}$ & $\mathrm{X}$ & $\mathrm{X}$ & $\mathrm{X}$ & $\mathrm{X}$ \\
\hline Legitimate Use of Force & $\mathrm{X}$ & & $\mathrm{X}$ & & $\mathrm{X}$ \\
\hline Reform & & & & & \\
\hline Democracy & $\mathrm{X}$ & $\mathrm{X}$ & $\mathrm{X}$ & $\mathrm{X}$ & $\mathrm{X}$ \\
\hline Unity of Effort & $\mathrm{X}$ & $\mathrm{X}$ & $\mathrm{X}$ & $\mathrm{X}$ & $\mathrm{X}$ \\
\hline Resettlement & & & & & \\
\hline Cost-Benefit & $\mathrm{X}$ & & $\mathrm{X}$ & & $\mathrm{X}$ \\
\hline Border Control & $\mathrm{X}$ & & $\mathrm{X}$ & & $\mathrm{X}$ \\
\hline Initiative & $\mathrm{X}$ & & $\mathrm{X}$ & & $\mathrm{X}$ \\
\hline Crush Them & $\mathrm{X}$ & & $\mathrm{X}$ & $\mathrm{X}$ & $\mathrm{X}$ \\
\hline Amnesty/Rewards & & & $\mathrm{X}$ & & \\
\hline Strategic Communication & & & $\mathrm{X}$ & & \\
\hline COIN FM & $\mathrm{X}$ & & $\mathrm{X}$ & & $\mathrm{X}$ \\
\hline Clear, Hold, Build & $\mathrm{X}$ & & $\mathrm{X}$ & & $\mathrm{X}$ \\
\hline Beat Cop & $\mathrm{X}$ & & $\mathrm{X}$ & & $\mathrm{X}$ \\
\hline Boots on the Ground & $\mathrm{X}$ & & $\mathrm{X}$ & & $\mathrm{X}$ \\
\hline Put a Local Face on It & $\mathrm{X}$ & & $\mathrm{X}$ & & $\mathrm{X}$ \\
\hline Commitment and Motivation & $\mathrm{X}$ & $\mathrm{X}$ & $\mathrm{X}$ & $\mathrm{X}$ & $\mathrm{X}$ \\
\hline Tangible Support Reduction & $\mathrm{X}$ & & $\mathrm{X}$ & & $\mathrm{X}$ \\
\hline Intelligence & $\mathrm{X}$ & & $\mathrm{X}$ & & $\mathrm{X}$ \\
\hline Flexibility and Adaptability & $\mathrm{X}$ & $\mathrm{X}$ & $\mathrm{X}$ & $\mathrm{X}$ & $\mathrm{X}$ \\
\hline
\end{tabular}

Source: Created by author using approaches extracted from Paul et al., Paths to Victory: Lessons from Modern Insurgencies, Table S.1.

\section{$\underline{\text { Part 7: Conclusion }}$}

Using Table 9 as a reference, India obtained significant results each time it applied national weight behind counterinsurgency operations against communist insurgencies. In phases, one, three, and five India demonstrates the effective use of multiple counterinsurgency strategies to quell violence. Conversely, phases two and four highlight potential reasons why the insurgency continually found a way to resurface after relatively quick defeats. This case study does not demonstrate a poor start by the counterinsurgent, rather, it shows a swift accurate response each 
time it commits to counterinsurgency operations. The Naxalite case study illustrates a RAND study conclusion that repression is overall a poor counterinsurgency strategy although it does not determine the outcome of the case. ${ }^{258}$ This may help explain why the insurgents continually bounce back after losing a phase. Finally, this case exemplifies the point that insurgents require tangible support to continue fighting or build strength for the future.

\section{Case Study Comparison and Analysis}

The comparison and analysis of the two case studies derives from Table 10. The first finding consists of the counterinsurgency approaches never employed by India in either case study. The second consists of those approaches identified in both case studies. The third finding discusses those elements used against the Naxalites, but not in Sri Lanka. The fourth finding discusses the few anomalies discovered in this research.

${ }^{258}$ Paul et al., Paths to Victory: Lessons from Modern Insurgencies, 109. 
Table 10. Case Study Comparison

\begin{tabular}{|l|c|c|c|c|c|c|c|c|}
\hline & \multicolumn{3}{|c|}{ Naxalite } & \multicolumn{3}{c|}{ Sri Lanka } & \multicolumn{2}{c|}{ Naxalite } \\
\hline \multicolumn{1}{|c|}{ Approach } & PH I & PH II & PH III & PH I & PH II & PH III & PH IV & PH V \\
\hline Hearts and Minds & $\mathrm{X}$ & & & & $\mathrm{X}$ & $\mathrm{X}$ & & \\
\hline Pacification & $\mathrm{X}$ & & $\mathrm{X}$ & & $\mathrm{X}$ & $\mathrm{X}$ & & $\mathrm{X}$ \\
\hline Government Legitimacy & $\mathrm{X}$ & $\mathrm{X}$ & $\mathrm{X}$ & & & & $\mathrm{X}$ & $\mathrm{X}$ \\
\hline Legitimate Use of Force & $\mathrm{X}$ & & $\mathrm{X}$ & $\mathrm{X}$ & $\mathrm{X}$ & $\mathrm{X}$ & & $\mathrm{X}$ \\
\hline Reform & & & & & & & & \\
\hline Democracy & $\mathrm{X}$ & $\mathrm{X}$ & $\mathrm{X}$ & $\mathrm{X}$ & $\mathrm{X}$ & $\mathrm{X}$ & $\mathrm{X}$ & $\mathrm{X}$ \\
\hline Unity of Effort & $\mathrm{X}$ & $\mathrm{X}$ & $\mathrm{X}$ & & & & $\mathrm{X}$ & $\mathrm{X}$ \\
\hline Resettlement & & & & & & & & \\
\hline Cost-Benefit & $\mathrm{X}$ & & $\mathrm{X}$ & & $\mathrm{X}$ & & & $\mathrm{X}$ \\
\hline Border Control & $\mathrm{X}$ & & $\mathrm{X}$ & & & & & $\mathrm{X}$ \\
\hline Initiative & $\mathrm{X}$ & & $\mathrm{X}$ & & $\mathrm{X}$ & & & $\mathrm{X}$ \\
\hline Crush Them & $\mathrm{X}$ & & $\mathrm{X}$ & & & & $\mathrm{X}$ & $\mathrm{X}$ \\
\hline Amnesty/Rewards & & & $\mathrm{X}$ & & & & & \\
\hline Strategic Communication & & & $\mathrm{X}$ & & & & & \\
\hline COIN FM & $\mathrm{X}$ & & $\mathrm{X}$ & & $\mathrm{X}$ & & & $\mathrm{X}$ \\
\hline Clear, Hold, Build & $\mathrm{X}$ & & $\mathrm{X}$ & & $\mathrm{X}$ & & & $\mathrm{X}$ \\
\hline Beat Cop & $\mathrm{X}$ & & $\mathrm{X}$ & & $\mathrm{X}$ & & & $\mathrm{X}$ \\
\hline Boots on the Ground & $\mathrm{X}$ & & $\mathrm{X}$ & & $\mathrm{X}$ & & & $\mathrm{X}$ \\
\hline Put a Local Face on It & $\mathrm{X}$ & & $\mathrm{X}$ & & & & & $\mathrm{X}$ \\
\hline Commitment and Motivation & $\mathrm{X}$ & $\mathrm{X}$ & $\mathrm{X}$ & & $\mathrm{X}$ & & $\mathrm{X}$ & $\mathrm{X}$ \\
\hline Tangible Support Reduction & $\mathrm{X}$ & & $\mathrm{X}$ & & & & & $\mathrm{X}$ \\
\hline Intelligence & $\mathrm{X}$ & & $\mathrm{X}$ & & $\mathrm{X}$ & & & $\mathrm{X}$ \\
\hline Flexibility and Adaptability & $\mathrm{X}$ & $\mathrm{X}$ & $\mathrm{X}$ & & $\mathrm{X}$ & & $\mathrm{X}$ & $\mathrm{X}$ \\
\hline
\end{tabular}

Source: Created by author using approaches extracted from Paul et al., Paths to Victory: Lessons from Modern Insurgencies, Table S.1.

\section{Part 1: Finding One}

The first finding consists of the counterinsurgency approaches India never employed in either case study. India never successfully implemented any reforms. One of the major findings from the RAND study stated that government reforms "lead to a more durable post conflict 
peace. ${ }^{259}$ The Sri Lanka government did not institute the reforms India thought necessary to alleviate the grievances. Consequently, a few years after India withdrew from Sri Lanka the conflict continued between the LTTE and the government of Sri Lanka. ${ }^{260}$ Against the Naxalites, India attempted a number of different reforms. However, corruption, lack of enforcement, and other causes always prevented the full application of the reform from occurring. As a result, the root cause of the Naxalite insurgency continues to persist even into $2015 .^{261}$

India also failed to implement a resettlement approach successfully. Both case studies utilized selective resettlement. The Sri Lankan government actually worked at cross-purposes with India and moved ethnic Sinhalese people into Tamil areas. ${ }^{262}$ Against the Naxalites, India used resettlement to control portions of the population who resided in disadvantageous terrain. ${ }^{263}$ According to Kelly Greenhill’s research, resettlement “works only in those rare cases where promises made by the counterinsurgents actually are fulfilled and the quality of life actually is improved for the displaced population-i.e., where a culture of cooperation and co-optation can be inculcated.” ${ }^{264}$ However, the counterinsurgents never improved the quality of life of the resettled population, which as the RAND study found is indicative of a poor counterinsurgency

${ }^{259}$ Paul et al., Paths to Victory: Lessons from Modern Insurgencies, xxxi.

${ }^{260}$ G.H. Peiris, Twilight of the Tigers: Peace Efforts and Power Struggles in Sri Lanka (New Delhi: Oxford University Press, 2009), 19.

261 “Chhattisgarh: 44 Naxalites Held in Last Two Days,” Times of India, January 1, 2015, accessed January 29, 2015, http://timesofindia.indiatimes.com/india/Chhattisgarh-44-Naxalitesheld-in-last-two-days/articleshow/45714353.cms.

${ }^{262}$ Kadian, India's Sri Lanka Fiasco, 29.

${ }^{263}$ Kennedy and Purushotham, "Beyond Naxalbari: A Comparative Analysis of Maoist Insurgency and Counterinsurgency in Independent India," 843.

${ }^{264}$ Paul et al., Paths to Victory: Lessons from Modern Insurgencies, 100. 
approach. ${ }^{265}$ Therefore, the improper application of this approach caused negative linger effects in both cases.

\section{Part 2: Finding Two}

The second finding consists of those counterinsurgency approaches India employed in both case studies. India attempted pacification efforts and a classic hearts and minds approach in both case studies. While the RAND study found strong evidence in support of these strategies being effective, the results in these case studies varied based on the location of implementation. India was generally successful in creating positive perceptions in both cases, which provided time for development to occur. However, the development plan employed in Sri Lanka focused only in Jaffna and therefore minimized its effects. Additionally, this approach was limited to only the first phase against the Naxalites, which contributed to India's inability to solve the economic issues, associated with the conflict areas. Therefore, while appearances are necessary to allow development to occur, in neither case can India lay claim to executing a comprehensive and thus a successful hearts and mind campaign.

One approach India successful executed throughout both case studies was the legitimate use of force. In both cases military, para-military, militia, and the like all generally adhered to a code of conduct that portrayed the forces in a relatively positive light when compared to the insurgent. Additionally, during successful phases, India also demonstrated a high level of commitment and motivation towards executing operations. As Paths to Victory emphatically highlights, commitment and motivation are essential intangible elements that contribute to

\footnotetext{
${ }^{265}$ Paul et al., Paths to Victory: Lessons from Modern Insurgencies, 101.
} 
counterinsurgent success. ${ }^{266}$ Furthermore, during successful phases India exemplified the ability to adapt to the changing strategic, operational, and/or tactical environment.

One of the cornerstone elements in both cases stems from the ability to recruit local forces to increased force capacity and improve intelligence-gathering capability. More forces allowed India to execute clear and hold operations by freeing up combat power for offensive operations. These operations allowed them to gain and maintain the initiative throughout successful phases. Additionally, these forces helped to raise the costs for the insurgent as it became increasingly more difficult to operate under constant pressure. This effort was a little less successful in Sri Lanka because the LTTE skillfully avoided major confrontations with the Indian military, which preserved both their personnel and equipment. Nonetheless, India's military raised the stakes for the LTTE as they did with the Naxalites. The ability to conduct offensive operations occurred through the acquisition of accurate and timely intelligence. The local forces obtained this information through previous and newly established links and connections into the local network. The combinations of these elements also illustrate one of the key RAND findings that “effective COIN practices run in packs."267

The final element observed in both case studies was democracy. This study validates the RAND conclusion that democracy does not possess a great deal of explanatory power for success in counterinsurgency operations. ${ }^{268}$ The impetus behind this concept argues that democracy increases legitimacy and allows a way to resolve grievances, peacefully. ${ }^{269}$ However, while Sri Lanka held elections during India’s presence, numerous portions of the country did not vote or

\footnotetext{
${ }^{266}$ Paul et al., Paths to Victory: Lessons from Modern Insurgencies, xxiii.

267 Ibid.

${ }^{268}$ Ibid., 97.

${ }^{269}$ Ibid.
} 
experienced low voter turnout due to the threat of violence. Additionally, the Sri Lankan government essentially failed at the task of setting up elections in most of the Tamil dominated areas. The Indian military came to the rescue and flew election personnel and material into the north and portions of the east. ${ }^{270}$ This "herculean effort" was not enough to overcome the LTTE boycott and subsequent violence, which resulted in the election of an unrepresentative government. ${ }^{271}$ Against the Naxalites, India endured two long periods where they sought conflict resolution through the democratic process. Although elections took place, and at times the Naxalites adhered to the process, in the end the two sides never resolved the grievances.

\section{Part 3: Finding Three}

There are numerous approaches that India used against the Naxalites, but which it did not operationalize in its efforts in Sri Lanka. India achieved government legitimacy throughout the Naxalite insurgency. However, in Sri Lanka, the Sinhalese population for the most part challenged India’s legitimacy, while the Tamil population's perception changed from accepting their legitimacy to uncertainty and rejection amongst sub-Tamil groups. The crucial decision to support the Sri Lankan government over the detention and prosecution of LTTE members painted the Indian forces as collaborators with the Sinhalese government. This explains why the Tamil perceptions changed. The inability to attack this perception and narrative deteriorated India's ability to influence the population favorably. Additionally, supporting the Sinhalese police force only exacerbated the issue of achieving legitimacy through the eyes of the minority Tamil population.

India never achieved unity of effort in Sri Lanka while it always ensured it against the Naxalites. The divide between both governments in Sri Lanka prevented them from achieving

\footnotetext{
${ }^{270}$ Kadian, India's Sri Lanka Fiasco, 125.

${ }^{271}$ Ibid.
} 
unity of effort. Sri Lankan forces and the Sinhalese population were more than willing to let the IPKF reduce the LTTE fighting force. However, they continually undermined all other efforts, most notably the diplomatic efforts to resolve the conflict. Ultimately, the Sinhalese population did not seek the same political compromise that India envisioned. Additionally, India also failed to achieve unity of effort within their own government as evident by the lack of coordination between the military and the Research and Analysis Wing. ${ }^{272}$ The organizational and command structure of both entities prevented collaboration and synchronization of efforts. ${ }^{273}$ One result of the failure to share information was the inability of India to reduce tangible support for the LTTE.

Access to recruits, training, intelligence, money, and equipment are essential elements to any insurgency. The Indian military was woefully ignorant about the depth and sophistication of LTTE support. Essentially, the LTTE conducted uninhibited sustainment operations. This allowed them to preserve and build strength even as the India military applied pressure during phase two. The LTTE then waited for the right opportunity to strike, which occurred after India's departure from the conflict. Conversely, India continuously cut off or drastically reduced the external support for the Naxalites. Effectively this helped to suffocate the insurgency relatively quickly in phase one and three. In phase five unfortunately, India felt the negative effects of globalization as external connections boomed and the ability to control borders became infinitely more difficult. The inability to reduce tangible support is one of the reasons why India is still combating the Naxalites.

India successfully employed a "putting a local face on it” approach against the Naxalites, but not in Sri Lanka. As mentioned earlier, incorporating the local population into numerous security apparatuses greatly assisted India’s operations against the Naxalites. In Sri Lanka, India

\footnotetext{
${ }^{272}$ Mehta, “India's Counterinsurgency Campaign in Sri Lanka,” 169. 273 Ibid.
} 
also sought to put a local face on their operations, but failed to execute this approach successfully. The problem with the approach was India failed to realize the impact of using ethnic Sinhalese personnel as police in Tamil dominated areas. As a result, this approach further exasperated the ethnic divide and deteriorated the legitimacy of India’s intervention to protect the Tamil population.

The final element identified in only the Naxalite insurgency was the use of the "Crush Them” approach. The use of repression and collective punishment was evident in four of the five phases of the Naxalite case. Part of the explanation for this occurrence could be the use of less professional forces. One of the major elements for India was the recruitment and employment of local security forces. Generally, these forces lacked the discipline and formal training of typical professional forces. However, the paramilitary force in Andhra Pradesh, called the Greyhounds is an exception. The Greyhounds proved extremely proficient in counterinsurgency operations so much so that there are calls and efforts to duplicate the force in other areas. ${ }^{274}$ Another explanation could be that states possess more propensity for violence during domestic conflicts.

\section{$\underline{\text { Part 4: Finding Four }}$}

This research coded two approaches as anomalies based on the limited appearance of them in either case study. A few approaches presented themselves in both case studies, but their use was limited, which diminished their potential impact. The use of amnesty/rewards and the strategic communications are two approaches not systematically identified in this study. In both cases, India preferred to co-opt the population. While there was evidence that India recruited

274 “Centre Mulls Greyhounds-Like Forces,” New Indian Express [Chennai], January 16, 2013, accessed February 5, 2015, http://search.proquest.com/docview/1269538598?pqorigsite=summon; Sai K. P. Kiran, “Greyhounds Likely to Train Anti-Naxalite Team [thiruvananthapuram]," Times of India (Online) [New Delhi], December 18, 2013, accessed February 5, 2015, http://search.proquest.com/docview/1468688241?pq-origsite=summon. 
insurgents, the amount and degree to which India offered amnesty to the insurgents is unknown. Additionally, although India initiated a weapon buyback program in Sri Lanka the endeavor produced little to no substantial results. Acquiring old outdated weapons does not constitute success against an enemy, who employed sophisticated weaponry.

The last anomaly identified was the presence of a well-communicated narrative during phase three against the Naxalites. The political campaign message and platform that occurred simultaneously with India's operations during phase three of the Naxalite insurgency explains the one time occurrence of this approach. This research did not find a common cause or individual reasons for the lack of a strategic narrative during the other four phases. The absence of unity of effort between the Sri Lankan and Indian governments likely explains the lack of a clear message emanating from the counterinsurgent in that case.

\section{Conclusion}

This research focused on answering the question of how India’s counterinsurgency approach against the Naxalites compares to their experience in Sri Lanka. The initial hypothesis was that India’s Sri Lankan experience influenced their counterinsurgency approach towards future Naxalite operations. This research disproves the hypothesis. India’s counterinsurgency approaches against the Naxalites remained almost identical over seven decades. The apparent formative experience for India in Sri Lanka did not influence future domestic counterinsurgency operations against the Naxalites. There are two possible reasons for this conclusion. One, India determined that the external counterinsurgency intervention did not compare well with their domestic counterinsurgency operations. Two, India dismissed their external counterinsurgency operations as irrelevant towards future domestic insurgencies. 
Based on these findings, there are two recommendations for future research. The first involves investigating the difference between labeling and conducting counterinsurgency operations versus counterterrorism operations. In 1967, India passed the Unlawful Activities (Prevention) Act, which labeled the CPI-M and the LTTE as terrorist organizations. ${ }^{275}$ Based on that document and the subsequent amendments, India essentially labeled all insurgent elements as terrorists. This act provided the Indian government the authorities to restrict freedoms for select populations while easing the ability for the government to bring all the means necessary to restore state legitimacy. ${ }^{276}$ This topic brings a range of questions into the discussion of counterinsurgency. What benefits does a government gain in labeling a group a terrorist as opposed to an insurgent? Does the labeling allow the military to conduct operations differently? The answers to these questions and others might assist in understanding how India conducts domestic counterinsurgency operations.

The second recommendation for future research involves investigating the propensity for violence by a state against a domestic insurgency versus as a third party counterinsurgent. One of the findings from this study eluded to the possibility that a state may be more prone to use repressive measures against a domestic insurgency than an external one. Domestically, governments acting as counterinsurgents may be less inclined to acknowledge the validity of grievances and more inclined to enforce the rule of law through any means available. Conversely, an external actor may be more susceptible to take a neutral stance and therefore attempt to avoid acts of violence that inhibit future political reconciliation.

275 “The Unlawful Activities (Prevention) Act, 1967,” National Investigation Agency: Government of India, last modified December 17, 2008, accessed December 9, 2014, http://nia.gov.in/acts/the\%20unlawful\%20activities\%20\%28prevention\%29\%20act,\%2019 67\%20\%2837\%20of\%201967\%29.pdf.

${ }^{276}$ Ibid. 


\section{Appendix}

Hearts and Minds (2 of 4): "The central proposition is that development and modernity will give the population a positive stake in order and good governance and thus deprive insurgents of their support.”

- Short-term investments, improvements in infrastructure or development, or property reform occurred in the area of conflict that was controlled or claimed by the COIN force.

- In the area of conflict, the COIN force was not perceived as worse than the insurgents.

- Planned reconstruction/development improvements were substantially above the historical baseline.

- Reconstruction/development met at least two of these criteria: based on popular demand, initiated mainly at the village level, used local labor/created local jobs, aimed at selfempowerment of the people, and was sustainable.

Pacification (2 of 6): "These concepts emphasize the simultaneous pursuit of development and security, beginning on a small scale then expanding across geographic locales."

- A perception of security was created or maintained among populations in areas that the COIN force claimed to control.

- Short-term investments, improvements in infrastructure or development, or property reform occurred in the area of conflict that was controlled or claimed by the COIN force.

- The COIN force established and then expanded secure areas.

- Planned reconstruction/development improvements were substantially above the historical baseline.

- $\quad$ COIN force undertook all three of clear, hold, and build.

- Reconstruction/development met at least two of these criteria: based on popular demand, initiated mainly at the village level, used local labor/created local jobs, aimed at selfempowerment of the people, and was sustainable.

Government Legitimacy (1 of 2): "People offer their support to the side that they perceive as having the greatest legitimacy."

- Government leaders were selected in a manner considered just and fair by the majority of the population in the area of conflict.

- The majority of citizens viewed the government as legitimate in the area of conflict. 
Legitimate Use of Force (4 of 6): The population supports the force that they perceive as acting in their interest.

- The COIN force avoided excessive collateral damage, disproportionate use of force, or other illegitimate applications of force.

- COIN force collateral damage was not perceived by the population in the area of conflict as worse than the insurgents'.

- In the area of conflict, the COIN force was not perceived as worse than the insurgents.

- The perception of security was created or maintained among populations in areas that the COIN force claimed to control.

- COIN force did not employ the indiscriminate force.

- $\quad$ The COIN force did not employ practices considered beyond the pale by contemporary U.S. ethical standards.

Reform (4 of 5): Addresses the change in performance of the government and COIN forces.

- Government corruption reduced/good governance increased since the onset of the conflict.

- There were significant government reforms since the onset of conflict.

- There were significant ethical/professional/human rights-related military reforms since the onset of conflict.

- There were significant government or military reforms in this phase.

- Reforms were recognized/appreciated by the population in the area of conflict.

Democracy (1 of 4): "Democracy is advocated as a way to increase the legitimacy of a government and as a way to resolve grievances short of violence."

- The government is a functional democracy.

- The government is a partial or transitional democracy.

- Free and fair elections were held.

- The government respects human rights and allows a free press.

Unity of Effort (1 of 1): "Posits that successful COIN forces coordinate the efforts of all security forces, and the government more broadly, toward a unified purpose."

- Unity of effort/unity of command was maintained.

Resettlement (2 of 2): Is a form of population control to constrain the ability of the insurgent to influence the population.

- The COIN force resettled or removed civilian populations for population control.

- Relocated populations were sufficiently compensated, and their quality of life improved. 
Cost-Benefit (2 of 6): "Insurgencies are best viewed as systems and that COIN efforts should be evaluated in terms of how well they either raised the cost of inputs to the system or interfered with outputs."

- COIN force efforts resulted in increased costs for insurgent processes.

- COIN forces effectively disrupted insurgent recruiting.

- COIN forces effectively disrupted insurgent materiel acquisition.

- COIN forces effectively disrupted insurgent intelligence.

- COIN forces effectively disrupted insurgent financing.

- COIN forces effectively disrupted insurgent command and control.

Border Control (1 of 1): Refers to the ability of the COIN force to restrict insurgent support.

- The flow of cross-border insurgent support significantly decreased or remained dramatically reduced or largely absent.

Initiative (1 of 1): Refers to the ability of the COIN force to dictate the tempo offensively.

- Fighting in phase initiated primarily by COIN forces.

Crush Them (1 of 2): Focuses on the "kinetic elimination of both active insurgents and the support they need."

- The COIN force employed escalating repression.

- The COIN force employed collective punishment.

Amnesty/Rewards (2 of 3): A way to reduce both active insurgents and those who passively support their operations.

- An amnesty or reward program was in place.

- The amnesty program reduced the number of insurgents.

- Phase included significant disarmament, demobilization, and reintegration efforts beyond amnesty.

Strategic Communication (3 of 5): the "art for coordinated whole-of-government persuasion and influence efforts, synchronizing the communicative content of both words and deeds."

- COIN force and government actions were consistent with messages (delivering on promises).

- The COIN force maintained credibility with populations in the area of conflict (includes expectation management).

- Messages or themes cohered with the overall COIN approach.

- COIN force avoided creating unattainable expectations.

- Themes and messages were coordinated across all involved government agencies. 
COIN FM (4 of 9): "The process of separating the insurgents from the population, which provides popular support to improve intelligence collection and contributes to legitimacy."

- A perception of security was created or maintained among the population in areas that the COIN force claimed to control.

- Government corruption was reduced or good governance increased since the onset of the conflict.

- Insurgent-claimed grievances were substantially addressed since the onset of the conflict.

- The COIN force sought to engage and establish positive relations with the population in the area of conflict.

- The COIN force provided or ensured the provision of basic services in areas that it controlled or claimed to control.

- There were short-term investments, improvements in infrastructure or development, or property reform in the area controlled or claimed by the COIN force.

- The COIN force received substantial intelligence from the population in the area of conflict.

- The majority of the population in the area of conflict supported or favored the COIN force.

- $\quad$ The COIN force avoided culturally offensive behaviors and messages.

Clear, Hold, Build (2 of 3): Represents the process of removing insurgents from an area, keeping the insurgents out of that area, and then providing development to improve the area.

- COIN force undertook "clear" of "clear, hold, and build” in area of conflict.

- COIN force undertook "hold" of "clear, hold, and build" in area of conflict.

- COIN force undertook "build” of "clear, hold, and build” in area of conflict.

Beat Cop (4 of 9): Refers to the process of becoming extremely familiar with the population to establish and maintain their trust.

- The perception of security was created or maintained among populations in areas that the COIN force claimed to control.

- The COIN force employed local militias or irregular forces or engaged in or enabled community policing in areas that it controlled or claimed to control, and these militias did not work at cross-purposes with COIN or government forces.

- The COIN force received substantial intelligence from the population in the area of conflict.

- In the area of conflict, the COIN force was not perceived as worse than the insurgents.

- The COIN force sought to engage and establish positive relations with the population in the area of conflict.

- The COIN force employed "counter-gangs," "scouts," or "ferret forces" against insurgents.

- Significant numbers of largely effective police, paramilitary, militia, or other nonconventional military in COIN forces used.

- The government employed significant numbers of locally recruited military, paramilitary, militia, or police forces.

- COIN forces primarily deployed in a space-domination/passive presence role. 
Boots on the Ground (3 of 6): Advocates for an advantageous ratio of COIN forces in relation to the size of the population and insurgent forces.

- Perception of security created or maintained among populations in areas the COIN force claimed to control.

- The COIN force employed local militias or irregular forces or engaged in/enabled community policing in areas it controlled or claimed to control.

- The COIN force sought to engage and establish positive relations with the population in area of conflict.

- No parts of the area of conflict were no-go or otherwise denied to the COIN force.

- The COIN force included significant numbers of largely effective police, paramilitary, militia, or other nonconventional personnel.

- COIN forces primarily deployed in a space-domination/passive presence role.

Put a Local Face on It (4 of 5): "Local communities in insurgent-contested areas need security and development and that well-prepared indigenous forces serve most effectively in meeting those needs."

- The COIN force employed local militias or irregular forces or engaged in or enabled community policing in areas that it controlled or claimed to control, and these militias did not work at cross-purposes with COIN or government forces.

- The COIN force did not employ culturally inappropriate outsiders for a significant fraction of operations.

- Indigenous forces conducted the majority of COIN operations.

- The COIN force included significant numbers of largely effective police, paramilitary, militia, or other nonconventional military personnel who were locally recruited.

- Development was not predominantly provided by (or perceived as being provided by) an external actor.

Commitment and Motivation (4 of 8): "To defeat an insurgency, the government and COIN force must be committed to doing so."

- Insurgent force not individually superior to the COIN force by being either more professional or better motivated.

- COIN force or allies did not rely on looting for sustainment.

- COIN force and government did not have different goals/level of commitment or both had relatively low levels of commitment.

- Government did not sponsor or protect unpopular economic and social arrangements or cultural institutions.

- Government did not involve corrupt and arbitrary personalistic rule.

- Government type was not kleptocracy.

- Elites did not have perverse incentives to continue conflict.

- The country was not economically dependent on an external actor. 
Tangible Support Reduction (3 of 10): "This concept posits that it does not matter whether it is by reducing motives or by reducing physical opportunities/capabilities, the way to defeat an insurgency is to eliminate its tangible support."

- The flow of cross-border insurgent support significantly decreased or remained dramatically reduced or largely absent.

- Important external support to insurgents was significantly reduced.

- Important internal support to insurgents was significantly reduced.

- Insurgents' ability to replenish resources was significantly diminished.

- Insurgents were unable to maintain or grow their force size.

- COIN force efforts resulted in increased costs for insurgent processes.

- COIN forces effectively disrupted insurgent recruiting.

- COIN forces effectively disrupted insurgent materiel acquisition.

- COIN forces effectively disrupted insurgent intelligence.

- COIN forces effectively disrupted insurgent financing.

Intelligence (1 of 2): Refers to "actionable intelligence that drives successful COIN operations."

- Intelligence was adequate to support kill/capture or engagements on the COIN force's terms.

- Intelligence was adequate to allow COIN forces to disrupt insurgent processes or operations.

Flexibility and Adaptability (1 of 1): "Emphasizes the importance of the COIN force's ability to adapt quickly and effectively to changes in warfare."

- $\quad$ The COIN force did not fail to adapt to changes in adversary strategy, operations, or tactics.

Source: Data adapted from Paul et al., Paths to Victory: Lessons from Modern Insurgencies, 87135. 


\section{Bibliography}

Ahuja, Pratul, and Rajat Ganguly. "The Fire Within: Naxalite Insurgency Violence in India." Small Wars and Insurgencies 18, no. 2 (06 Dec 2007): 249-74. Accessed August 4, 2014. http://dx.doi.org/10.1080/09592310701400861.

Banerjee, Dipankar. "The Indian Army's Counterinsurgency Doctrine," in India and Counterinsurgency: Lessons Learned, edited by Sumit Ganguly and David Fidler, 189-206. New York: Routledge, 2009.

Bullion, Alan. India, Sri Lanka and the Tamil Crisis 1976-1994: An International Perspective. London: Cassell Publishers Ltd, 1995.

Callwell, C.E. Small Wars: Their Principles and Practice. London: Harrison and Sons, 1906.

Chakrabarti, Shantanu. "Evolving Insurgency and India's Counter-Insurgency Options: Entering Into the Age of Fourth-Generation Warfare." The Quarterly Journal 9, no. 2 (Spring 2010): 65-78. Accessed August 5, 2014. http://www.ciaonet.org/journals/co/v9i2/f_0019379_16588.pdf.

Clausewitz, Carl von. On War, Indexed Edition. Reprint ed. Princeton, NJ: Princeton University Press, 1989.

De Silva, K.M. Regional Powers and Small State Security: India and Sri Lanka, 1977-1990. Edited by Professor K. M. De Silva. Washington, DC: The Johns Hopkins University Press, 1995.

Edwardes, Michael. Nehru, a Political Biography. New York: Praeger Publishers, 1972.

Fair, C. Christine. Urban Battle Fields of South Asia: Lessons Learned from Sri Lanka, India, and Pakistan. Santa Monica: RAND Corporation, 2004.

Fidler, David P. "The Indian Doctrine for Sub-Conventional Operations: Reflections from a U.S. Counterinsurgency Perspective." In India and Counterinsurgency: Lessons Learned, edited by Sumit Ganguly and David P. Fidler, 205-29. New York: Routledge, 2009.

Field Manual 3-24, Insurgencies and Countering Insurgencies. Washington, DC: Government Printing Office, 2014.

Florig, William R. "The Red Scourge Returns: The Strategic Challenge of Maoist Insurgency in India and South Asia." Master's thesis, U.S. Army War College, 2008.

Gahlot, Pramod. "Efficacy of Effects Based Operations On Maoist Coin Operations in India." Master's thesis, Marine Corps University, 2012.

Galula, David. Counterinsurgency Warfare: Theory and Practice. St. Petersburg, FL: Hailer, 2005.

Ganguly, Sumit, and David Fidler, eds. India and Counterinsurgency: Lessons Learned. New York: Routledge, 2009. 
Gratton, Chris, and Ian Jones. Research Methods for Sport Studies. New York: Routledge, 2004.

Harnetiaux, Keith J. "The Resurgence of Naxalism: How Great a Threat to India." Master's thesis, Naval Postgraduate School, 2008.

Harriss, John. "What is going on in India's 'red corridor'? Questions about India's Maoist insurgency." Pacific Affairs 84, no. 2 (June 2011): 309-27.

Iyer, Lakshmi. "The Bloody Millennium: Internal Conflict in South Asia." Harvard Business School Working Paper, No. 09-086, January 2009.

Jayasekera, P.V.J., ed. Security Dilemma of a Small State: Sri Lanka in the South Asian Context. Part One. New Delhi: South Asian Publishers Pvt. Ltd., 1992.

Joes, Anthony J. Resisting Rebellion: The History and Politics of Counterinsurgency. Lexington, KY: The University of Kentucky, 2004.

Johnson, Burke, and Larry B. Christensen. Educational Research: Quantitative, Qualitative, and Mixed Approaches. 3rd ed. Thousand Oaks, CA: SAGE Publications, 2008.

Joint Publication 3-24, Counterinsurgency. Washington, DC: Government Printing Office, 2013.

Kadian, Rajesh. India's Sri Lanka Fiasco. New Delhi: Vision Books Pvt Ltd, 1990.

Kalyvas, Stathis N. The Logic of Violence in Civil War. NEW YORK: Cambridge University Press, 2006.

Keerawella, Gamini. Security Dilemma of a Small State: Internal Crisis and External Intervention in Sri Lanka. Part Two. Edited by Mahinda Werake and P.V.J. Jayasekera. New Delhi: South Asian Publishers Pvt. Ltd., 1995.

Kennedy, Jonathan, and Sunil Purushotham. "Beyond Naxalbari: A Comparative Analysis of Maoist Insurgency and Counterinsurgency in Independent India." Comparative Studies in Society and History 54, no. 4 (2012): 832-62. Accessed August 4, 2014. http://dx.doi.org/10.1017/S0010417512000436.

Kilcullen, David. The Accidental Guerrilla: Fighting Small Wars in the Midst of a Big One. New York: Oxford University Press, 2009.

. "Two Schools of Classical Counterinsurgency." Small Wars Journal (January 27, 2007): 1. Accessed September 30, 2014. http://smallwarsjournal.com/blog/two-schools-ofclassical-counterinsurgency.

Kitson, Frank. Bunch of Five. London: Faber and Faber, 2011.

Kotwali, Dinesh. "The Naga Insurgency: The Past and the Future." Strategic Analysis Vol XXIV, no. 4 (July 2000): 751-72. Accessed February 3, 2015. http://www.idsa-india.org/an-jul700.html. 
Lalwani, Sameer. "India's Approach to Counterinsurgency and the Naxalite Problem." CTC Sentinel 4, no. 10 (October 2011): 5-9. Accessed August 5, 2014.

https://www.ctc.usma.edu/posts/india's-approach-to-counterinsurgency-and-the-naxaliteproblem.

Long, Austin. On "Other War" Lessons from Five Decades of RAND Counterinsurgency Research. Santa Monica: RAND Corporation, 2006.

Maneuver Self-Study Program. "Nature and Character of War and Warfare." April 25, 2014. Accessed August 10, 2014. http://www.benning.army.mil/mssp/Nature and Character/.

Marks, Thomas. "Counterinsurgency and Operational Art." Low Intensity Conflict and Law Enforcement 13, no. 3 (2005): 168-211. Accessed August 5, 2014. http://www.tandfonline.com/doi/pdf/10.1080/09662840600560527.

Maoist Insurgency Since Vietnam. London: Frank Cass \& CO. LTD, 1996.

Mehta, Ashok K. "India's Counterinsurgency Campaign in Sri Lanka." In India and Counterinsurgency: Lessons Learned, edited by Sumit Ganguly and David P. Fidler, 15572. New York: Routledge, 2009.

Metcalf, Barbara D., and Thomas R. Metcalf. A Concise History of Modern India. 2nd ed. Cambridge: Cambridge University Press, 2006.

Miklian, Jason. "The Purification Hunt: The Salwa Judum Counterinsurgency in Chhattisgarh, India." Dialect Anthropol 33 (27 October 2009): 441-59.

Mockaitis, Thomas. "The British Experience in Counterinsurgency 1919-1960." PhD diss., University of Wisconsin-Madison, 1988.

Mukherjee, Anit. "India's Experiences with Insurgency and Counterinsurgency." In The Routledge Handbook of Asian Security Studies, edited by Sumit Ganguly, Joseph Liow, and Andrew Scobell, 140-59. London: Routledge, 2010.

National Investigation Agency: Government of India. "The Unlawful Activities (Prevention) Act, 1967." Last modified December 17, 2008. Accessed December 9, 2014. http://nia.gov.in/acts/the\%20unlawful\%20activities\%20\%28prevention\%29\%20act,\%2019 67\%20\%2837\%20of\%201967\%29.pdf.

Oetken, Jennifer L. “Counterinsurgency against Naxalites in India.” In India and Counterinsurgency: Lessons Learned, edited by Sumit Ganguly and David P. Fidler, 12551. New York: Routledge, 2009.

Palhari, Anup K. "Unequal Rebellions: The continuum of "Peoples War" in Nepal and India." In The Maoist Insurgency in Nepal: Revolution in the Twenty-First Century, edited by Mahendra Lawoti and Anup K. Pahari, 195-216. New York: Routledge, 2010. Accessed February 5, 2015. https://books.google.com/books?id=KtGNAgAAQBAJ\&pg=PR10\&lpg=PR10\&dq= Part+V:+Military+and+state+dimension.+The+Maoist+Insurgency+in+Nepal:+Revolution + in+the+Twenty-first+Century.\&source=bl\&ots=sC_gXEMxeK\&sig=lw9wYS4NBxkrOqWbcaOtPmjz7g\&hl=en\&sa=X\&ei=4JfTVO-. 
Paul, Christopher, Colin Clarke, Beth Grill, and Molly Dunigan. Paths to Victory: Lessons from Modern Insurgencies. Santa Monica, CA: RAND Corporation, 2013.

Paul, Christopher, Colin P. Clarke, and Beth Grill. Victory Has a Thousand Fathers: Sources of Success in Counterinsurgency. Santa Monica, CA: RAND Corporation, 2010.

Peiris, G.H. Twilight of the Tigers: Peace Efforts and Power Struggles in Sri Lanka. New Delhi: Oxford University Press, 2009.

Rajagopalan, Rajesh. Fighting Like a Guerrilla: the Indian Army and Counterinsurgency. New Delhi: Routledge India, 2008.

. "Innovations in Counterinsurgency: The Indian Army's Rashtriya Rifles." Contemporary South Asia 13, no. 1 (March 2004): 25-37.

Ram, Mohan. Maoism in India. New York: Barnes \& Noble, 1971.

Rana, LT COL KMS "An Analysis of the Indian Army's Coin Experience." Master's thesis, United States Army Command and General Staff College, 2012.

Rich, Paul, and Isabelle Duyvesteyn, eds. The Routledge Handbook of Insurgency and Counterinsurgency. New York: Routledge, 2012.

Rid, Thomas, and Thomas Keaney, eds. Understanding Counterinsurgency: Doctrine, Operations, and Challenges. New York: Routledge, 2010.

Sahukar, Behram A. "The Indian Approach to Counterinsurgency Operations." Insurgency Research Group. March 6, 2008. Accessed November 20, 2014.

http://insurgencyresearchgroup.wordpress.com/2008/03/06/the-indian-approach-tocoin/the-indian-approach-to-counterinsurgency-operations/.

Selected Works from Mao Tse-Dong. "Problems of Strategy in China's Revolutionary War." 2004. Accessed December 9, 2014.

http://www.marxists.org/reference/archive/mao/selected-works/volume-1/mswv1_12.htm.

Simpson, Emile. War from the Ground Up: Twenty-First Century Combat as Politics (Crises in World Politics). New York: Oxford University Press, 2012.

Singh, Prakash. "Irregular Warfare: The Maoist Challenge to India's Internal Security." JSOU Report 12-9, December 2012.

Stuster, J. Dana "To Coin or Not?: A decade later, what lessons haven't we learned from the war in Iraq that we should?" Foreign Policy, March 18, 2013. Accessed October 21, 2014. http://www.foreignpolicy.com/articles/2013/03/18/to_coin_or_not.

Tilly, Charles. Coercion, Capital, and European States, AD 990-1992. Rev. ed. Cambridge, MA: Wiley-Blackwell, 1992.

Trinquier, Roger. A French View of Counterinsurgency. Fort Leavenworth, KS: Combat Studies Institute Press, U.S Army Command and General Staff College, 1985. 
Turabian, Kate L. A Manual for Writers of Research Papers, Theses, and Dissertations, Eighth Edition: Chicago Style for Students and Researchers (Chicago Guides to Writing, Editing, and Publishing). 8th ed. Chicago: University Of Chicago Press, 2013.

Van Evera, Stephen. Guide to Methods for Students of Political Science. Ithaca: Cornell University Press, 1997.

Werake, Mahinda, and P.V.J. Jayasekera, eds. Security Dilemma of a Small State. Internal Crisis and External Intervention in Sri Lanka 2. New Delhi: South Asian Publishers Pvt. Ltd., 1995. 